\author{
UNIVERSIDADE DE SÃO PAULO \\ ESCOLA DE ENGENHARIA DE SÃO CARLOS \\ DEPARTAMENTO DE HIDRÁULICA E SANEAMENTO
}

DANILO NAGATA AYABE

Co-digestão anaeróbia de glicerol residual com esgoto sanitário visando o aumento da produção de metano.

VERSÃO CORRIGIDA

São Carlos, SP.

2018 



\section{DANILO NAGATA AYABE}

\section{Co-digestão anaeróbia de glicerol residual com esgoto sanitário visando o aumento}

da produção de metano.

Dissertação apresentada à Escola de Engenharia de São Carlos da Univesidade de São Paulo, como parte dos requisitos para obtenção do título de Mestre Em Ciências: Engenharia Hidráulica e Saneamento.

Orientador: Prof. Titular Eugenio Foresti

São Carlos 


\section{AUTORIZO A REPRODUÇÃO TOTAL OU PARCIAL DESTE TRABALHO, POR QUALQUER MEIO CONVENCIONAL OU ELETRÔNICO, PARA FINS DE ESTUDO E PESQUISA, DESDE QUE CITADA A FONTE.}

Ficha catalográfica elaborada pela Biblioteca Prof. Dr. Sérgio Rodrigues Fontes da EESC/USP com os dados inseridos pelo(a) autor(a).

Ayabe, Danilo Nagata
A973c Co-digestão anaeróbia de glicerol residual com esgoto sanitário visando o aumento da produção de metano / Danilo Nagata Ayabe; orientador Eugenio Foresti. São Carlos, 2018.

Dissertação (Mestrado) - Programa de Pós-Graduação em Engenharia Hidráulica e Saneamento e Área de Concentração em Hidráulica e Saneamento -- Escola de Engenharia de São Carlos da Universidade de São Paulo, 2018 .

1. Digestão Anaeróbia. 2. Co-digestão anaeróbia. 3. Metano. 4. Glicerol. 5. UASB. 6. Esgoto Sanitário. I. Título.

Eduardo Graziosi Silva - CRB - 8/8907 
Candidato: Engenheiro DANILO NAGATA AYABE.

Título da dissertação: "Co-digestão anaeróbia de glicerol residual com esgoto sanitário visando o aumento da produção de metano".

Data da defesa: 01/10/2018.

Comissāo Julgadora:

Prof. Titular Eugenio Foresti

(Orientador)

(Escola de Engenharia de São Carlos/EESC)

Prof. Dr. Theo Syrto Octavio de Souza

(Escola Politécnica/EP-USP)

Prof. Dr. Dagoberto Yukio Okada

(Universidade Estadual de Campinas/UNICAMP)

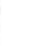

Resultado:

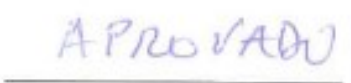





\section{AGRADECIMENTOS}

Ao professor Eugenio Foresti pela orientação, oportunidade, pelo grande apoio, compreensão e pelo grande exemplo de profissional e cidadão.

À todos os professores que tive durante os períodos de graduação e pósgraduação, pelo inestimável conhecimento passado.

Aos colegas de LPB pela ótima convivência e pela grande ajuda durante todo o período experimental.

À todos os amigos feitos durante todos esses anos em São Carlos, pelos diversos momentos de descontração.

À minha família, pelo apoio incondicional.

Ao CNPq, pelo apoio financeiro.

Meus sinceros agradecimentos. 



\section{RESUMO}

AYABE, D. N. Co-digestão anaeróbia de glicerol residual com esgoto sanitário visando o aumento da produção de metano. Dissertação (Mestrado) - Escola de Engenharia de São Carlos, Universidade de São Paulo, São Carlos. 2018.

A crescente preocupação com os impactos ambientais causados pela utilização de combustíveis fósseis, assim como a escassez dos mesmos, tem estimulado o desenvolvimento de tecnologias de produção de energia limpa e renovável nos últimos anos. No Brasil, o biodiesel tem sido um combustível renovável de destaque, principalmente pelo aumento das concentrações mínimas obrigatórias em que o biodiesel deve estar presente na produção de óleo diesel, previstas por lei. O aumento da geração de biodiesel causa o aumento da geração de glicerol, um resíduo altamente poluente que apesar de ter valor comercial na indústria, os altos custos de purificação e o aumento da oferta estão tornando o processo de remoção de impurezas do glicerol financeiramente insustentável. Dentro desse contexto, o presente trabalho teve como objetivo agregar valor ao glicerol residual através do aumento da produção de biogás com potencial energético em reator anaeróbio de manta de lodo e fluxo ascendente (UASB). A utilização de processo co-digestivo com esgoto sanitário teve como pressuposto o aproveitamento da riqueza nutricional do esgoto e a possibilidade do aumento da produção de metano em reatores UASB tratando esgoto municipal, amplamente encontrados pelo país. O reator foi operado continuamente com tempo de detenção hidráulica (TDH) de 8 horas, onde a carga orgânica volumétrica (COV) foi expressa em termos de demanda química de oxigênio (DQO), em um aumento progressivo de 1,74 até $6,92 \mathrm{kgDQO} / \mathrm{m}^{3}$.dia ao longo de 280 dias de operação. Foi possível concluir que a adição de glicerol ao esgoto sanitário é adequada para o aumento da produção de metano. A operação do reator se manteve estável até a aplicação de COV de 5,68 $\mathrm{kgDQO} / \mathrm{m}^{3}$. dia, quando foi possível atingir $95 \%$ de metano no biogás, remoção de $85 \%$ de DQO e valores próximos ao potencial teórico de produção de metano obtido em teste de atividade metanogênica específica (AME). A limitação do processo se deu na COV de $6,92 \mathrm{kgDQO} / \mathrm{m}^{3}$.dia, quando o reator passou a apresentar indícios de colapso com o desbalanceamento de valores de $\mathrm{pH}$ e diminuição na produção de biogás. As baixas concentrações de $\mathrm{CO}_{2}$ no biogás em todas as fases experimentais sustentaram uma hipótese de ocorrência de atividade homoacetogênica no reator em uma relação de sinergismo com as comunidades da digestão anaeróbia.

Palavras-chave: Digestão anaeróbia. Co-digestão anaeróbia. Metano. Glicerol. UASB. Esgoto sanitário. 



\begin{abstract}
AYABE, D. N. Anaerobic co-digestion of crude glycerol and sewage to increase methane production. Dissertation (Master's degree) - School of Engineering of São Carlos, University of São Paulo, São Carlos. 2018.
\end{abstract}

In recent years, there has been a growing concern about the environmental impacts caused using fossil fuels, as well as their scarcity, which stimulates the development of technologies of production of renewable energy. In Brazil, biodiesel has been a prominent renewable fuel, mainly due to the increase in the minimum concentration, provided by law, in which biodiesel must be present in diesel oil. Increased biodiesel production causes increased generation of glycerol. Despite having commercial value in the chemical industry, glycerol is a highly polluting waste that has high purification costs, which are becoming financially unsustainable due to the increase of supply. In this context, the present work aimed to aggregate value to the residual glycerol by increasing the biogas production through the increase of methane in a upflow anaerobic sludge blanket (UASB) reactor. The choice to use a co-digestive process with sanitary sewage had as a presupposition the use of the nutritional diversity of the sewage and the the possibility to increase methane production in UASB reactors treating municipal sewage, widely found in Brazil. The reactor was continuously operated with hydraulic detention time $(\mathrm{TDH})$ of 8 hours, where the organic loading rate (OLR) was expressed in terms of chemical oxygen demand (COD), in a progressive increase from 1.74 to 6.92 $\mathrm{kgCOD} / \mathrm{m}^{3}$.d in 280 days of operation. It was possible to conclude that the addition of glycerol to the sanitary sewage is adequate for the increase of methane production. The operation of the reactor remained stable until the application of OLR of 5.68 $\mathrm{kgCOD} / \mathrm{m}^{3} . \mathrm{d}$, when it was possible to reach $95 \%$ of methane in the biogas, removal of $85 \%$ of COD and values close to the theoretical potential of methane production obtained in a specific methanogenic activity test (SMA). The limitation of the process occurred in the OLR of $6.92 \mathrm{kgCOD} / \mathrm{m}^{3} . \mathrm{d}$, when the reactor started to show signs of collapse with the imbalance of $\mathrm{pH}$ values and a decrease in biogas production. The low concentrations of $\mathrm{CO}_{2}$ in the biogas in all experimental phases supported a hypothesis of homoacetogenic activity in the reactor in a synergistic relationship with the anaerobic digestion communities.

Key-words: Anaerobic Digestion. Anaerobic co-digestion. Methane. Glycerol. UASB. Sewage. 



\section{LISTA DE FIGURAS}

Figura 3.1 - Estrutura química do Glicerol.

Figura 3.2 - Equação de formação de glicerol e biodiesel a partir da transesterificação de triglicerídeo. 4

Figura 3.3 - Via redutora do metabolismo do glicerol............................................. 6

Figura 3.4 - Via oxidativa de metabolismo do glicerol. ............................................. 7

Figura 3.5 - Esquema simplificado da digestão anaeróbia (adaptado de Lettinga et al., 1999). 16

Figura 4.1 - Glicerol residual bruto utilizado. ....................................................... 21

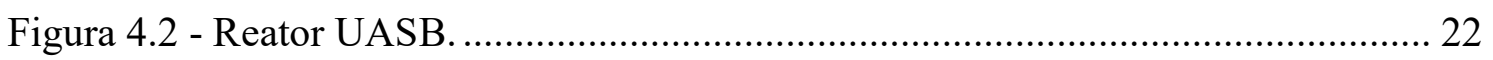

Figura 5.1 - Variação temporal dos valores de COV aplicados................................... 26

Figura 5.2 - Gráfico box-plot dos valores de COV aplicados. ................................. 27

Figura 5.3 - Variação dos valores de DQO afluente e efluente. ................................... 30

Figura 5.4 - Gráfico box-plot dos valores de eficiência de remoção de DQO................ 31

Figura 5.5 - Variação dos valores de DQO Filtrada afluente e efluente. ....................... 32

Figura 5.6 - Gráfico box-plot dos valores de eficiência de remoção de DQO filtrada... 33

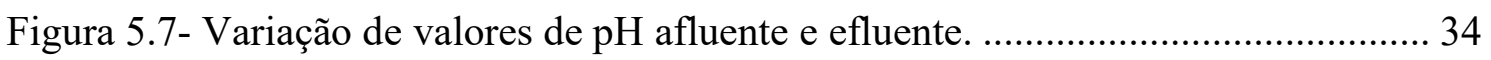

Figura 5.8 - Variação de valores de alcalinidade afluente e efluente. ........................... 36

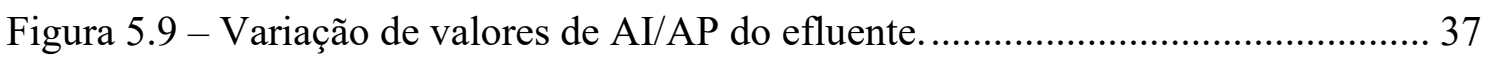

Figura 5.10 - Variação dos valores de ácidos voláteis totais ao longo das fases

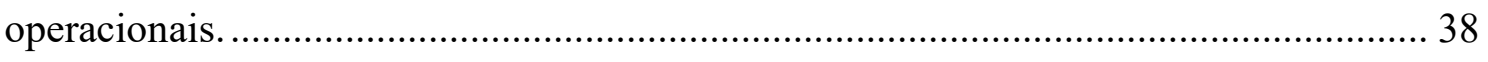

Figura 5.11 - Variação dos valores de ácido acético, propiônico e butírico afluente.... 39

Figura 5.12- Variação dos valores de ácido acético, propiônico e butírico efluente..... 40

Figura 5.13 - Variação de valores de produção de biogás. .......................................... 41

Figura 5.14 - Composição do biogás produzido ao longo das fases operacionais. ........ 43

Figura 5.15 - Rendimento da produção de metano.................................................... 46 
Figura 5.16 - Gráfico box-plot do rendimento da produção de metano durante as fases

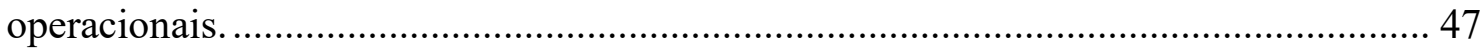




\section{LISTA DE TABELAS}

Tabela 3.1 - Levantamento de valores de COV aplicados em processos de co-digestão

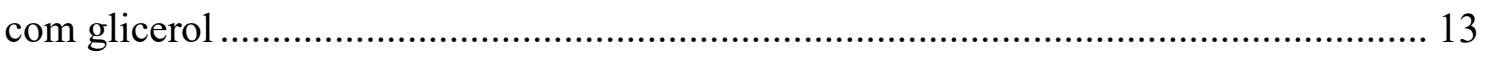

Tabela 4.1 - Características do esgoto sanitário a ser utilizado.................................... 20

Tabela 4.2 - Características da primeira solução de glicerol utilizada. ......................... 21

Tabela 4.3 - Análises de monitoramento do reator e suas respectivas frequências e métodos

Tabela 4.4 - Soluções de macro e micronutrientes utilizadas nos testes de AME......... 25

Tabela 5.1 - Valores médios de COV ao longo das fases operacionais........................2 26

Tabela 5.2 - Valores médios de DQO afluente e efluente ao longo das fases operacionais

Tabela 5.3 - Levantamento de valores de remoção de DQO e tempos de detenção hidráulica em trabalhos de co-digestão anaeróbia com glicerol

Tabela 5.4 - Valores médios de DQO Filtrada afluente e efluente ao longo das fases operacionais

Tabela 5.5 - Valores médios de $\mathrm{pH}$ afluente e efluente ao longo das fases operacionais.

Tabela 5.6 - Valores médios de alcalinidade afluente e efluente. 35

Tabela 5.7 - Valores médios de ácidos voláteis totais afluente e efluente. 38

Tabela 5.8 - Valores de ácido acético, propiônico e butírico afluente nas últimas fases operacionais

Tabela 5.9 - Valores de ácido acético, propiônico e butírico efluente nas últimas fases operacionais

Tabela 5.10 - Valores de produção de biogás nas fases operacionais

Tabela 5.11 - Valores médios da composição do biogás produzido.

Tabela 5.12 - Rendimento na produção de metano ao longo das fases operacionais..... 46

Tabela 5.13 - Cálculos realizados a partir do teste de AME 49 



\section{LISTA DE SIGLAS}

AI: alcalinidade intermediária;

AP: alcalinidade parcial;

AGCL: ácidos graxos de cadeia longa;

AME: atividade metanogênica específica;

COV: carga orgânica volumétrica;

DBO: demanda bioquímica de oxigênio;

DQO: demanda química de oxigênio;

ETE: estação de tratamento de esgoto;

pH: potencial hidrogeniônico;

ST: sólidos totais;

SST: sólidos suspensos totais;

SSV: sólidos suspensos voláteis;

TDH: tempo de detenção hidráulica;

UASB: reator anaeróbio de manta de lodo e fluxo ascendente (upflow anaerobic sludge blanket). 



\section{SUMÁRIO}

1. INTRODUÇÃO 1

2. OBJETIVOS 3

3. REVISÃO BIBLIOGRÁFICA 4

3.1. Glicerol 4

3.2. Rotas metabólicas de fermentação do glicerol 5

3.3. Co-digestão anaeróbia em tratamento de efluentes 9

3.4. Co-digestão anaeróbia utilizando glicerol residual 9

3.5. Reaproveitamento de metano produzido em reatores anaeróbios 14

3.6. Homoacetogênese na digestão anaeróbia 15

3.7. Atividade Metanogênica Específica 18

$\begin{array}{ll}\text { 3.8. Considerações } & 19\end{array}$

4. MATERIAL E MÉTODOS 20

4.1. Esgoto Sanitário 20

$\begin{array}{ll}\text { 4.2. Glicerol } & 20\end{array}$

$\begin{array}{ll}\text { 4.3. Reator } & 22\end{array}$

$\begin{array}{ll}\text { 4.3.1. Partida } & 22\end{array}$

$\begin{array}{lll}\text { 4.3.2. Operação } & 23\end{array}$

4.3.3. Métodos Analíticos 23

4.4. Atividade metanogênica específica 24

5. RESULTADOS E DISCUSSÃO 26

5.1. Carga Orgânica Volumétrica (COV) 26

$\begin{array}{lll}\text { 5.2. } & \mathrm{DQO} & 27\end{array}$

$\begin{array}{ll}\text { 5.2.1. DQO bruta } & 27\end{array}$

5.2.2. DQO filtrada 32

5.3. $\mathrm{pH}$ e alcalinidade $\quad 34$ 
5.4. Ácidos voláteis

5.5. Produção de Biogás 41

5.6. Composição do biogás 42

5.7. Rendimento na produção de metano 46

5.8. Atividade metanogênica específica 48

6. CONCLUSÕES 50

7. REFERÊNCIAS BIBLIOGRÁFICAS, 51 


\section{INTRODUÇÃO}

O aumento da produção de biodiesel no mundo é consequência do aumento da preocupação com a utilização de combustíveis fósseis, uma vez que a produção de biocombustíveis pode ser considerada como alternativa renovável e ambientalmente sustentável.

No Brasil, o histórico de leis as quais definem que o óleo diesel deve contar com percentual mínimo de biodiesel está atualmente em transição, sendo que em julho de 2008 o percentual mínimo de biodiesel era de 4\% (BRASIL, 2009a), passando para 5\% a partir do início de 2010 (BRASIL, 2009b), 6\% a partir de julho de 2014 (BRASIL, 2014) e chegando a prever um percentual mínimo de $8 \%$ até 2017 , de $9 \%$ até 2018 e de 10\% até março de 2019 (BRASIL, 2016).

O principal subproduto da produção de biodiesel trata-se de um resíduo com alta carga orgânica, o glicerol. A proporção de geração de glicerol e produção de biodiesel é de cerca de $10 \%(\mathrm{v} / \mathrm{v})$, através de processo de transesterificação. O glicerol, por sua vez, possui alto valor comercial em diversos processos industriais, principalmente no setor de produtos cosméticos. Porém, os processos industriais que utilizam o glicerol como matéria-prima requerem-no em índices de pureza elevados, geralmente acima de 95\%.

O glicerol produzido a partir da produção de biodiesel possui teor de pureza variável, usualmente abaixo do requerido para ser utilizado como matéria-prima, tornando a sua utilização muitas vezes inviável. Os processos de purificação do glicerol são custosos e, com o aumento da produção de biodiesel, o subproduto tem seu preço cada vez menor a ponto de tornar a purificação economicamente insustentável. Além disso, o glicerol residual possui alto potencial poluidor, por apresentar alta concentração de matéria orgânica, sendo que os valores médios de DQO são de aproximadamente 1.260 g/L (Viana, 2011), e também pela possível presença de óleos, sais, ácidos graxos de cadeia longa, metanol, entre outros.

A utilização de glicerol como co-substrato em processos de tratamento anaeróbio de águas residuárias torna-se atrativa pelo fato de que possui alta concentração orgânica prontamente biodegradável, podendo aumentar a produção de metano em reatores convencionais de tratamento de esgoto sanitário. As principais 
premissas de processos de co-digestão anaeróbia são: o aproveitamento de nutrientes em excesso/falta em diferentes efluentes e a diminuição do efeito tóxico ou inibidor de certa água residuária através da diluição. Os principais trabalhos recentemente publicados sobre a co-digestão anaeróbia de glicerol envolvem outros co-substratos com alta carga orgânica, em reatores (digestores) com alto tempo de detenção hidráulica. O presente trabalho teve uma abordagem em que co-digestão ocorreu em reator anaeróbio tratando diretamente esgoto sanitário, com características menos concentradas.

Os reatores anaeróbios de manta de lodo e fluxo ascendente (reatores UASB) têm sido amplamente utilizados no Brasil para tratamento de esgoto sanitário. Comparados aos tradicionais sistemas aeróbios de lodos ativados, possuem como principais vantagens o baixo custo operacional, baixa produção de lodo e o potencial de geração de energia (elétrica ou térmica) através do metano, o principal constituinte do biogás gerado nos reatores.

No Brasil, a utilização do biogás gerado em estações de tratamento de esgotos para geração de energia é considerada uma das soluções energéticas para sustentabilidade das estações no futuro (Probiogás, 2015). No entanto, o esgoto apresenta baixas concentrações de matéria orgânica facilmente degradável. Assim, aproveitamento do potencial energético do metano contido no biogás gerado por reatores UASB não é realizado, ainda, devido, provavelmente, ao custo associado às instalações de purificação do biogás e operação dos sistemas de geração de energia, em vista às baixas produções de metano. Esses fatores podem tornar antieconômico o investimento em aproveitamento do biogás.

A partir desse contexto, o presente trabalho teve como objetivo aumentar a produção de metano a partir de processo de co-digestão anaeróbia de esgoto sanitário e glicerol, aproveitando os nutrientes em abundância na água residuária municipal e a elevada carga orgânica do glicerol, com intuito de avaliar a viabilidade do aproveitamento energético do biogás gerado. 


\section{OBJETIVOS}

O presente trabalho teve como objetivo principal avaliar a fração de glicerol ideal para que um reator anaeróbio de manta de lodo e fluxo ascendente (UASB) tratando esgoto sanitário tenha sua produção de metano aumentada, até o limite da sua estabilidade operacional.

Os objetivos específicos do trabalho foram:

- Avaliar o potencial de geração de metano a partir do glicerol;

- Obter a fração ótima de glicerol afluente ao reator UASB, em termos de carga orgânica, nas condições estipuladas, sem a adição de álcalis para controle do pH. 


\section{REVISÃO BIBLIOGRÁFICA}

\subsection{Glicerol}

O glicerol (glicerina ou 1,2,3-propanetriol) é um álcool, sem cor e sem odor, viscoso e não tóxico. A Figura 3.1 mostra a estrutura química do Glicerol.

Figura 3.1 - Estrutura química do Glicerol.

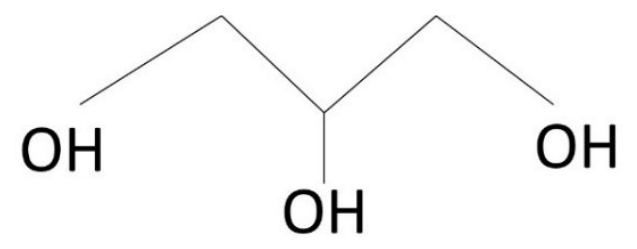

Uma das maneiras em que o glicerol pode ser produzido é pela transesterificação de triglicerídeos (óleo vegetal ou gordura animal) em reação com um álcool e na presença de um catalisador químico (base forte), para obtenção de ésteres metílicos de ácidos graxos (biodiesel), conforme apresentado na equação da Figura 3.2.

Figura 3.2 - Equação de formação de glicerol e biodiesel a partir da transesterificação de triglicerídeo.

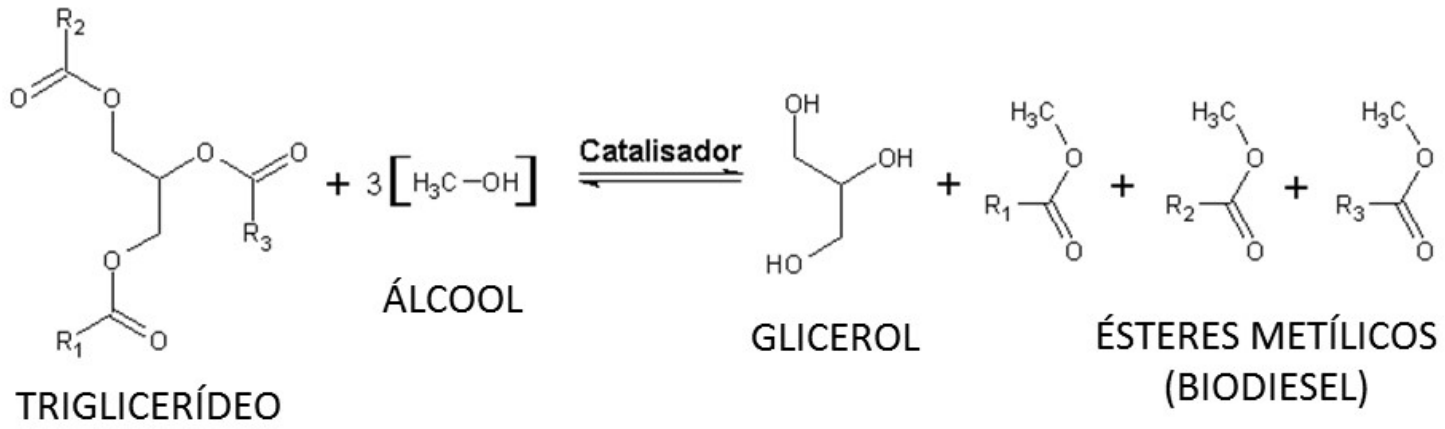

A produção de biodiesel se tornou relevante nos últimos anos com objetivo de substituir os combustíveis fósseis. De acordo com Santos (2012), o biodiesel produzido no Brasil será de 40 milhões de metros cúbicos e a produção mundial passará de 100 milhões de metros cúbicos, em 2035. O glicerol é o principal subproduto da produção de biodiesel, sendo estimado que a cada $9 \mathrm{~kg}$ de biodiesel produzido, $1 \mathrm{~kg}$ de glicerol residual é formado (Dasari et al., 2005). 
Atualmente, os principais usos do glicerol residual são a produção de produtos químicos; produção de compostos poliméricos; produção de biocombustíveis e biogás e a reutilização de glicerol após processo de purificação (Monteiro et al., 2018).

O glicerol, com 95\% ou mais de pureza, é utilizado como matéria prima de diversos processos industriais, como na indústria de cosméticos, de automóveis, de alimentos, farmacêutica, de papel, entre outros (Wang et al., 2001). Porém, o glicerol encontrado a partir da produção de biodiesel possui menor índice de pureza, podendo variar de acordo com o tipo de óleo vegetal ou animal e de acordo com o próprio processo de produção de biodiesel, com média de valores de aproximadamente entre 50 a $60 \%$ de pureza (Slinn et al., 2008). A purificação da glicerina residual da produção de biodiesel é realizada a partir de diversos processos, entre eles o método convencional, em que se realiza o pré-tratamento com ácido (clorídrico e/ou fosfórico), neutralização, evaporação e refino por destilação (Gervajio, 2005), o método de troca iônica (Javani et al., 2005), ou separação por membranas (Javani et al., 2005).

Estima-se que, em 2020, a produção mundial de glicerol será de 3 milhões de toneladas enquanto que a demanda comercial não ultrapassará de 500 mil toneladas (Lin, 2013). Assim, é importante que se encontrem opções alternativas para se utilizar glicerol considerando o aumento da produção de biodiesel.

Segundo Monteiro et al. (2018), a produção de biodiesel ainda apresenta cenário favorável para certas alterações no processo produtivo para utilização de métodos com maior eficiência afim de obter produtos e subprodutos com maior valor agregado e mais sustentabilidade na cadeia de produção.

O tratamento biológico do glicerol se torna uma alternativa viável, uma vez que podem ser gerados mais compostos energéticos como o metano, a partir de processos anaeróbios (Poleto et al., 2016).

\subsection{Rotas metabólicas de fermentação do glicerol}

A degradação biológica do glicerol é realizada por diversos microrganismos, uma vez que esse composto pode ser encontrado naturalmente no meio ambiente, por ser parte constituinte de óleos e gorduras de origem animal ou vegetal. 
Produtos com valor econômico agregado como 1,3-propanodiol, hidrogênio, etanol, ácido docosa-hexanoico, poliésteres e lipídeos podem ser gerados a partir de glicerol residual através de processos biológicos (Baba et al., 2013). O tratamento anaeróbio de um meio contendo glicerol pode ser realizado por um grande número de microrganismos que o utilizam como fonte de carbono, de acordo com rotas metabólicas fermentativas já bem estabelecidas (Viana, 2011).

A via redutora de metabolização consiste na conversão de glicerol a 3hidroxipropinaldeído, onde é gerada uma molécula de água utilizando a enzima glicerol desidratase como catalisadora e posteriormente à 1,3-propanodiol pela enzima 1,3propanodiol oxidorredutase, oxidando o $\mathrm{NADH}_{2}$, conforme apresentado na Figura 3.3 (Biebl et al., 1999).

Figura 3.3 - Via redutora do metabolismo do glicerol.

Fonte: adaptado de Biebl et al. (1999) e Simões (2017).

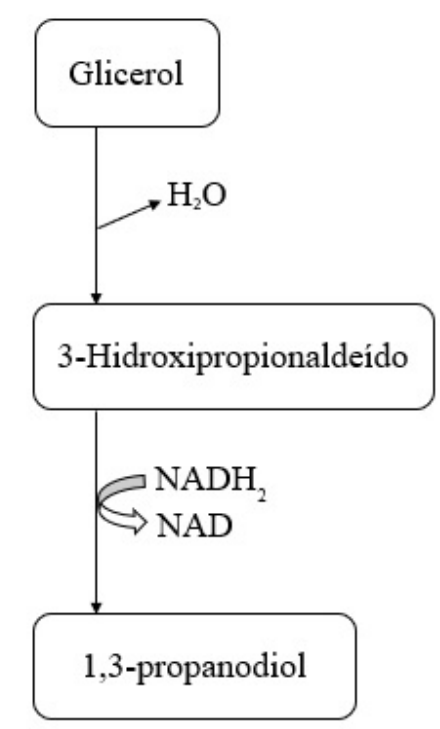

O rendimento teórico de geração de 1,3-propanodiol a partir de glicerol é de uma proporção de 1:1 mol, conforme Equação 1.

$$
\mathrm{C}_{3} \mathrm{H}_{8} \mathrm{O}_{3}+\mathrm{H}_{2} \rightarrow \mathrm{C}_{3} \mathrm{H}_{8} \mathrm{O}_{2}+\mathrm{H}_{2} \mathrm{O}
$$


O 1,3-propanodiol possui um amplo campo de aplicação, por ser um intermediário para a síntese de compostos cíclicos e monômero para polímeros (Costa, 2017). Porém, para a produção de biogases de poder energético, como o hidrogênio e o metano, é desejável que a fermentação do glicerol seja realizada pela via oxidativa.

A rota oxidativa de metabolização do glicerol se inicia através da enzima glicerol desidrogenase, para formação do composto dihidroxiacetona (Biebl, 1999). As condições ambientais e as enzimas presentes guiam as reações posteriores para formação de compostos mais simples (Simões, 2017), conforme apresentado na Figura 3.4 .

Figura 3.4 - Via oxidativa de metabolismo do glicerol.

Fonte: adaptado de Biebl et al. (1999), Costa (2017) e Simões (2017).



Para que possa ocorrer a geração de metano pelas Methanosaeta sp., Methanosarcina sp., Methanobacterium sp. e Methanospirillum devem estar presentes no reator os microrganismos formadores de formiato, acetato, hidrogênio e dióxido de carbono. Essas espécies são conhecidas como arqueias metanogênicas, que utilizam o hidrogênio e o acetato para produzir metano. 
A geração dos compostos utilizados para a geração de metano é realizada em um equilíbrio dinâmico entre bactérias fermentativas, acidogênicas, acetogênicas e as arqueias metanogênicas. As bactérias fermentativas hidrolisam polímeros e matéria orgânica particulada em substâncias mais simples e/solúveis. As bactérias acidogênicas convertem os compostos orgânicos gerados na hidrólise em compostos inorgânicos, ácidos orgânicos voláteis e em hidrogênio. As bactérias acetogênicas convertem os produtos da acidogênese em acetato, hidrogênio e dióxido de carbono.

As principais impurezas que podem afetar o tratamento biológico, por serem consideradas tóxicas ou recalcitrantes, que são encontradas no glicerol oriundo da produção de biodiesel são: ácidos graxos de cadeia longa (AGCL), cloretos, sulfatos e sulfetos (Viana, 2011). Os AGCL provêm dos triglicerídeos que participam da reação de transesterificação e ficam dissolvidos no glicerol. Os cloretos, sulfatos e sulfetos são oriundos da etapa de acidificação, em que são utilizados ácido clorídrico ou sulfúrico.

O rendimento teórico de geração de metano a partir do glicerol é dado de acordo com a Equação 2:

$\mathrm{C}_{3} \mathrm{H}_{8} \mathrm{O}_{3} \rightarrow 1,75 \mathrm{CH}_{4}+1,25 \mathrm{CO}_{2}+0,5 \mathrm{H}_{2} \mathrm{O}$

(Equação 2)

De acordo com Zhang et al. (2015), a reação teórica apresentada na equação (2) pode ser afetada por condições ambientais e operacionais, além de desequilíbrio entre velocidades de geração e de conversão de ácido acético $\left(\mathrm{CH}_{3} \mathrm{COOH}\right)$ em metano, diminuindo o rendimento de acordo com a Equação 3:

$\mathrm{C}_{3} \mathrm{H}_{8} \mathrm{O}_{3} \rightarrow \mathrm{CH}_{3} \mathrm{COOH}+0,75 \mathrm{CH}_{4}+0,25 \mathrm{CO}_{2}+0,5 \mathrm{H}_{2} \mathrm{O}$

(Equação 3)

O possível acúmulo de acetato, a homoacetogênese, a baixa concentração de metano e de dióxido de carbono estão discutidas em outros tópicos do presente trabalho. 


\subsection{Co-digestão anaeróbia em tratamento de efluentes}

$\mathrm{O}$ balanço nutricional adequado, além da temperatura e do $\mathrm{pH}$, são os principais fatores ambientais para que a digestão anaeróbia ocorra com desempenho satisfatório, em que as bactérias responsáveis pelo tratamento da água residuária possam crescer e se reproduzir. Os principais macronutrientes essenciais para os processos biológicos são o Nitrogênio $(\mathrm{N})$ e o Fósforo $(\mathrm{P})$, sendo que a relação DQO:N:P de 500:5:1 é considerada suficiente em processos anaeróbios (Speece \& McCarty, 1964). Além do N e P, em revisão sobre as necessidades nutricionais de organismos metanogênicos, Speece (1996) cita que o enxofre (S), ferro, magnésio, manganês, cobalto, níquel, molibdênio, selênio e vitamina $B_{12}$ são nutrientes essenciais para que ocorra a metanogênese.

A co-digestão biológica para tratamento de águas residuárias tem como objetivos principais o fornecimento de nutrientes para dois ou mais tipos de efluentes, para que possa se compensar a falta ou excesso dos mesmos nas águas residuárias (Chernicharo, 2007). Além disso, pode ocorrer o alívio de cargas tóxicas ou inibidoras através da diluição (Xie et al., 2016) e a otimização da cinética de produção de metano (Mata-Alvarez et al., 2011). Além disso, também se acredita que o aumento da produção de metano poderá aumentar o grau de mistura dentro do reator, diminuindo as resistências à transferência de massa entre o substrato e o biofilme.

O número limitado de estudos envolvendo processos de co-digestão indica que há a necessidade de se conceber e executar experimentos nesse contexto, assim como propor modelos matemáticos para os mesmos (Xie et al., 2016). Segundo Grosser (2017), a utilização de baixos tempos de detenção hidráulica em processos co-digestivos específicos ainda é um grande desafio e precisa de estudos para identificação das melhores condições de aplicação do processo.

\subsection{Co-digestão anaeróbia utilizando glicerol residual}

O glicerol residual pode não conter as concentrações adequadas dos nutrientes para suprir as demandas dos microrganismos para realização de suas atividades metabólicas, além de poder conter elementos tóxicos ou que causem inibição da digestão anaeróbia (Viana, 2011). Dessa forma, a co-digestão de glicerol residual com 
outras águas residuárias também poderá ter o efeito de diluição de constituintes tóxicos. Dentro desse contexto, diversos trabalhos envolvendo a co-digestão de glicerol com diferentes tipos de resíduos foram desenvolvidos.

Nuchdang \& Phalakornkule (2012) compararam a digestão anaeróbia de glicerol como único composto afluente com a co-digestão de glicerol com estrume de porco em reatores UASB, variando os valores de tempo de detenção hidráulico (TDH) e carga orgânica volumétrica (COV). Nos resultados apresentados, foi possível observar que o reator de co-digestão apresentou maior capacidade de assimilação de diminuição de TDH e aumento de COV, em relação à remoção de DQO e produção de biogás. O melhor desempenho do reator de co-digestão foi atribuído, pelos autores, ao fornecimento de nutrientes contidos no resíduo de suinocultura. Além disso, o reator alimentado com apenas glicerol apresentou acúmulo de intermediários (ácido propiônico e butírico), o que não ocorreu no reator de co-digestão. Os valores de COV de 1,3 a $1,7 \mathrm{kgDQO} / \mathrm{m}^{3}$.dia no reator de co-digestão tiveram remoção de DQO acima de $90 \%$ e produção de metano de 0,10 a $0,21 \mathrm{~L} \mathrm{CH}_{4} / \mathrm{g}$ DQO removida. Já para os valores de $\mathrm{COV}$ de 2,9 a 5,0 kgDQO $/ \mathrm{m}^{3}$.dia, foi observada diminuição da produção de metano para valores menores que $0,10 \mathrm{~L} \mathrm{CH}_{4} / \mathrm{g}$ DQO removida, atribuída à inibição por competição observada com o aumento da produção de gás sulfídrico.

Fountoulakis et al. (2010) avaliaram a co-digestão de glicerol residual com lodo de estação de tratamento de esgoto sanitário em reatores contínuos. Para adição de $1 \%$ (v/v) de glicerol, foi observado que o reator apresentou estabilidade operacional de $90 \%$ de remoção de DQO. Por outro lado, a aplicação de 3\% (v/v) de glicerol causou a inibição da atividade bacteriana. $\mathrm{O}$ colapso do sistema foi atribuído, principalmente, à sobrecarga orgânica, uma vez que foi observado o decaimento de $\mathrm{pH}$ de 6,5 para 5,3, indicando acúmulo de ácidos voláteis no reator e diminuição considerável de remoção de DQO, consequentemente.

Athanasoulia et al. (2014) avaliaram, também, a co-digestão de lodo de estação de tratamento de esgoto e glicerol em reatores anaeróbios de mistura completa em condições mesofílicas. Foram avaliadas diferentes porcentagens de glicerol no afluente e em diferentes valores de TDH. A produção de biogás aumentou de 3,8 a 4,7 vezes quando as concentrações de glicerol no mistura foram de $2 \%$ e $3 \%(\mathrm{v} / \mathrm{v})$, em COV equivalentes à valores entre 1,0 a $1,7 \mathrm{kgDQO} / \mathrm{m}^{3}$.dia. O acúmulo de ácidos 
intermediários e diminuição da produção de biogás foi observada com a concentração de $4 \%$ de glicerol no sistema.

Baba et. al. (2013) avaliaram o processo de co-digestão em reator de $30 \mathrm{~m}^{3}$ de volume útil (reator de escala plena) de glicerol com lodo de estação de tratamento de água residuária de indústria de macarrão instantâneo. Os resultados obtidos foram comparados com a produção teórica de metano obtida por cálculos estequiométricos, em que $350 \mathrm{ml}$ de metano é produzido a partir de $1 \mathrm{~g}$ DQO removida. Além disso, os resultados foram comparados com trabalho realizado por Castrillón et al. (2011), em que se realizou a co-digestão de glicerol com estrume de gado, onde foram obtidos valores de $211 \mathrm{~mL} \mathrm{CH}_{4} / \mathrm{gDQO}$ removida (condição mesofílica) e $348 \mathrm{~mL} \mathrm{CH} / \mathrm{gDQO}$ removida (condição termofílica), além do trabalhos realizados por Siles et al. (2010) e Siles López et al. (2009), onde se obtiveram, respectivamente, valores de $310 \mathrm{~mL}$ $\mathrm{CH}_{4} / \mathrm{gDQO}$ removida e $356 \mathrm{~mL} \mathrm{CH} / \mathrm{gDQO}$ removida para co-digestão de glicerol com lodo de estação de tratamento de efluente de cervejaria. No trabalho em questão, foi atingida produção de metano de $358 \mathrm{~mL} \mathrm{CH}_{4} / \mathrm{gDQO}$ removida para $\mathrm{COV}$ de 1,48 $\mathrm{kgDQO} / \mathrm{m}^{3}$.dia, concluindo-se que é possível se realizar co-digestão envolvendo glicerol em reatores de escala plena, obtendo-se valores de produção de metano próximos ao teórico e aos obtidos em laboratório. Para $\mathrm{COV}$ de 3,69 $\mathrm{kgDQO} / \mathrm{m}^{3}$.dia, o sistema apresentou decréscimo significante de $\mathrm{pH}$.

A co-digestão de glicerol bruto e lodo de esgoto proveniente de estação com sistema de lodos ativados foi avaliada por Kurahashi et al. (2017). Para concentração de glicerol de 0,126 a $1,26 \mathrm{~g} / \mathrm{L}$, foi observada produção estável de metano nos reatores, já nas concentrações de 2,52 a 7,57 g/L observou-se uma maior produção de hidrogênio, ácidos orgânicos e 1,3-propanodiol durante os primeiros dias de operação, e o metano passou a ser gerado a partir de certos períodos de estabilização. O estudo mostrou que a co-digestão com o lodo possui versatilidade, uma vez que apenas a variação da proporção de glicerol aplicado permitiu a produção de diferentes compostos. Os autores concluíram que o processo co-digestivo com glicerol permitiu que o tipo de lodo utilizado tivesse estabilizado e seu volume diminuído, além de possuir potencial de geração de compostos com valor agregado.

Rodríguez-Abalde et al. (2017) avaliaram a co-digestão de glicerol com resíduo de abatedouro de aves com estrume de porco em reator semi-contínuo para geração de metano. A mistura dos três substratos em carga de $3,2 \mathrm{kgDQO} / \mathrm{m}^{3}$.dia e TDH de 32 dias 
apresentou eficiência de remoção de DQO de 55\% e 71\% de composição de $\mathrm{CH}_{4}$ no biogás. Nessa condição o reator não apresentou instabilidade em relação à composição de ácidos orgânicos e à alcalinidade. Os autores atribuíram o bom desempenho do reator ao bom balanço nutricional $(\mathrm{C} / \mathrm{N})$ resultante da mistura entre os três efluentes, porém acreditam que o sistema possuía margem de crescimento para produção de metano se fosse aplicado um maior TDH.

Zahedi et al. (2018) avaliaram a co-digestão de lodo de ETE com glicerol em reator semi-contínuo em condição mesofílica, com aumento gradual da carga aplicada, utilizando como parâmetros de monitoramento ácidos orgânicos, alcalinidade e pH. O reator apresentou estabilidade para $\mathrm{COV}$ de $2,03 \mathrm{kgDQO} / \mathrm{m}^{3}$.dia, pequeno desequilíbrio em $2,89 \mathrm{kgDQO} / \mathrm{m}^{3}$.dia e desestabilização total em $4,05 \mathrm{kgDQO} / \mathrm{m}^{3}$.dia. A perspectiva do trabalho buscou se atentar ao tempo de retenção de sólidos (STR), inversamente proporcional à COV. Concluiu-se que em STR típico de estações de tratamento, de $12 \mathrm{a}$ 15 dias, a co-digestão estudada seria interessante para redução de custos e geração de metano.

A Tabela 3.1 mostra um levantamento, a partir de dados da literatura, de outros experimentos encontrados e dos previamente citados. A COV "estável" se trata dos valores em que os experimentos tiveram estabilidade operacional para remoção de DQO e produção de metano e a COV "colapso" se trata de valores onde os reatores tiveram queda de rendimento. As COVs apresentadas no levantamento da Tabela 3.1 são referentes aos valores de DQO total de cada estudo, onde são levados em conta a DQO do glicerol e do co-substrato. 
Tabela 3.1 - Levantamento de valores de COV aplicados em processos de co-digestão com glicerol

\begin{tabular}{|c|c|c|c|c|}
\hline Co-substrato & $\begin{array}{l}\text { Regime de } \\
\text { Operação }\end{array}$ & $\begin{array}{l}\text { COV "estável" } \\
\left(\mathrm{kgDQO} / \mathrm{m}^{3} . d i a\right)\end{array}$ & $\begin{array}{l}\text { COV "colapso" } \\
\left(\mathrm{kgDQO} / \mathrm{m}^{3} . \mathrm{dia}\right)\end{array}$ & Fonte \\
\hline Esterco Suíno & Contínuo & 1,3 a 1,7 & 2,9 a 5,0 & $\begin{array}{l}\text { Nuchdang \& } \\
\text { Phalakornkule } \\
\text { (2012) }\end{array}$ \\
\hline $\begin{array}{c}\text { Lodo ETE } \\
\text { (esgoto sanitário) }\end{array}$ & Contínuo & $(*)(1 \%)$ & $(*)(3 \%)$ & $\begin{array}{c}\text { Fountoulakis et } \\
\text { al. (2010) }\end{array}$ \\
\hline Esterco Suíno & $\begin{array}{l}\text { Semi- } \\
\text { contínuo }\end{array}$ & 2,5 & $(*)$ & $\begin{array}{l}\text { Wohlgemut } \\
\text { (2009) }\end{array}$ \\
\hline $\begin{array}{c}\text { Lodo ETE } \\
\text { (esgoto sanitário) }\end{array}$ & $\begin{array}{l}\text { Contínuo } \\
\text { (CSTR) }\end{array}$ & 1,0 a 1,7 & $2,4(* *)$ & $\begin{array}{c}\text { Athanasoulia et } \\
\text { al. (2014) }\end{array}$ \\
\hline $\begin{array}{l}\text { Lodo ETE } \\
\text { (macarrão } \\
\text { instantâneo) }\end{array}$ & Contínuo & 1,48 & 3,69 & $\begin{array}{l}\text { Baba et. al. } \\
\quad \text { (2013) }\end{array}$ \\
\hline $\begin{array}{c}\text { Lodo ETE } \\
\text { (processamento de } \\
\text { batata) }\end{array}$ & Contínuo & 2,2 & $(*)$ & Ma et al. (2008) \\
\hline $\begin{array}{l}\text { Água residuária de } \\
\text { Usina de Biodiesel }\end{array}$ & Contínuo & 4,5 & $(*)$ & $\begin{array}{l}\text { Siles et al. } \\
\text { (2010) }\end{array}$ \\
\hline $\begin{array}{c}\text { Resíduo de } \\
\text { abatedouro de aves } \\
+ \text { Estrume de } \\
\text { porco }\end{array}$ & $\begin{array}{l}\text { Semi- } \\
\text { contínuo }\end{array}$ & 3,2 & $(*)$ & $\begin{array}{l}\text { Rodríguez- } \\
\text { Abalde et al. } \\
\text { (2017) }\end{array}$ \\
\hline Lodo ETE & $\begin{array}{l}\text { Semi- } \\
\text { contínuo }\end{array}$ & 2,03 & 4,05 & $\begin{array}{l}\text { Zahedi et al. } \\
\quad(2018)\end{array}$ \\
\hline
\end{tabular}

(*): valor não apresentado.

$(* *)$ : valor estimado pelo autor a partir de cálculos.

A Tabela 3.1 mostra que os valores de COV "estável" e de "colapso" variam muito e podem ser atribuídos a uma série de fatores como: regime de operação, condições hidrodinâmicas, equilíbrio nutricional, variações nas características do glicerol, entre outros.

Vale ressaltar que os co-substratos utilizados foram lodos de estações de tratamento ou efluentes concentrados, em que as condições de digestão anaeróbia ocorreram em reatores com elevado tempo de detenção. O presente trabalho teve como objetivo utilizar um reator que trata esgoto sanitário municipal, operando com baixo tempo de detenção hidráulica em comparação com outros trabalhos. No geral, os fatores limitantes em efluentes diluídos, como o esgoto sanitário, são a carga hidráulica e a velocidade ascensional, enquanto que em efluentes concentrados a limitação é a carga 
orgânica. Dessa forma, buscou-se a associação da melhor condição de aplicação de cargas orgânica e hidráulica.

\subsection{Reaproveitamento de metano produzido em reatores anaeróbios}

A digestão anaeróbia de matéria orgânica presente em efluentes e resíduos domésticos, industriais e agropecuários permite o aproveitamento do biogás gerado, principalmente pelo potencial energético do metano. A utilização de biogás é considerada como fonte alternativa e renovável de energia, sendo significativamente cada vez mais utilizada para esse fim.

O metano é um combustível primário e possui potencial de $47 \mathrm{MJ} / \mathrm{kg}$, sob condição de $101,3 \mathrm{kPa}$ e $0^{\circ} \mathrm{C}$. De toda a energia disponível no tratamento de esgoto sanitário, os sistemas anaeróbios têm o potencial de recuperar $53 \%$ como calor e $28 \%$ como eletricidade, sendo o restante utilizado como necessidades energéticas microbianas e como entropia nos processos de produção de energia (McCarty et al., 2011).

No Brasil pode-se considerar que o aproveitamento de biogás está muito abaixo do seu potencial, considerando sua elevada população concentrada em centros urbanos, expressiva produção agropecuária e industrial (Zanette, 2009) e o clima favorável à aplicação de processos anaeróbios.

O biogás gerado em reatores anaeróbios é constituído por alto teor de metano (70 a 80\%), e em menores quantidades, nitrogênio, dióxido de carbono e gás sulfídrico (Noyola et al., 2006). Os constituintes gasosos são liberados em forma de biogás quando atingem concentrações acima das concentrações de saturação no meio líquido. Assim, a quantificação do volume em que cada constituinte será liberado como biogás é calculada segundo a lei de Henry, a partir de valores de pressão parcial e concentração de saturação para diferentes gases.

A viabilidade financeira da utilização do biogás é definida a partir de uma série de fatores. Uma parcela significativa dos equipamentos utilizados no reaproveitamento deve ser importada (Probiogás, 2015), existe a perda de metano dissolvido no efluente, vazamentos através de tubos, conexões e coletores, acúmulo de escuma, reatores em que são tratados efluentes muito diluídos (Prosab, 2011), reatores mal projetados ou 
construídos (Probiogás, 2015), além de perdas relacionadas à de limpeza das unidades de coleta e armazenamento de biogás (Valente, 2015).

A presença de metano dissolvido em efluente de reatores anaeróbios é indesejável pois o metano pode formar atmosferas explosivas (Cookney et al., 2015). Além disso, sua liberação à atmosfera reflete no aumento da emissão de gás que contribui com o efeito estufa e também refletiria na perda de fonte potencial de energia (Heneares et al., 2018). A estimativa da quantidade de metano dissolvido em efluentes de reatores anaeróbios é tipicamente feita através da Lei de Henry, porém estudos recentes mostram que esse valor pode ser muito maior, mostrando uma condição de supersaturação (Crone et al., 2016). Um modelo de simulação criado por Lobato et al. (2012) estimou que perdas de 22, 30 e 46\% para respectivos cenários de melhor, típico e pior situação, para reatores UASB tratando esgoto sanitário entre 20 e $30^{\circ} \mathrm{C}$.

O aproveitamento de metano a partir do biogás gerado se torna viável em diferentes faixas de escala (Zanette, 2009). O aumento da população atendida torna o processo mais viável, principalmente, pela relação entre geração de biogás e custo dos equipamentos que devem ser adquiridos. Em estudo realizado por Valente (2015), foi avaliada a viabilidade em diferentes ETEs e diferentes opções (arranjos) de cogeração de energia. No geral, para as opções estudadas, foi possível definir uma opção que apresentou viabilidade econômica de aproveitamento do biogás para uma população mínima de 100.000 habitantes. As taxas financeiras internas de retorno poderiam chegar em $80 \%$ em ETEs de maior porte, em que a abrangência é de 200.000 a 450.000 habitantes.

\subsection{Homoacetogênese na digestão anaeróbia}

A digestão anaeróbia é um processo complexo que envolve diversas classes de microrganismos. As suas principais fases são bem estabelecidas: hidrólise, acidogênese, acetogênese e metanogênese, sendo que diversos compostos intermediários são consumidos por certos microrganismos enquanto são produzidos por outros, sendo assim um processo auto-regulado que se opera por sinergismo. A Figura 3.5 mostra um esquema simplificado da digestão anaeróbia, onde matéria orgânica complexa é convertida até metano. 
Figura 3.5 - Esquema simplificado da digestão anaeróbia (adaptado de Lettinga et al., 1999).

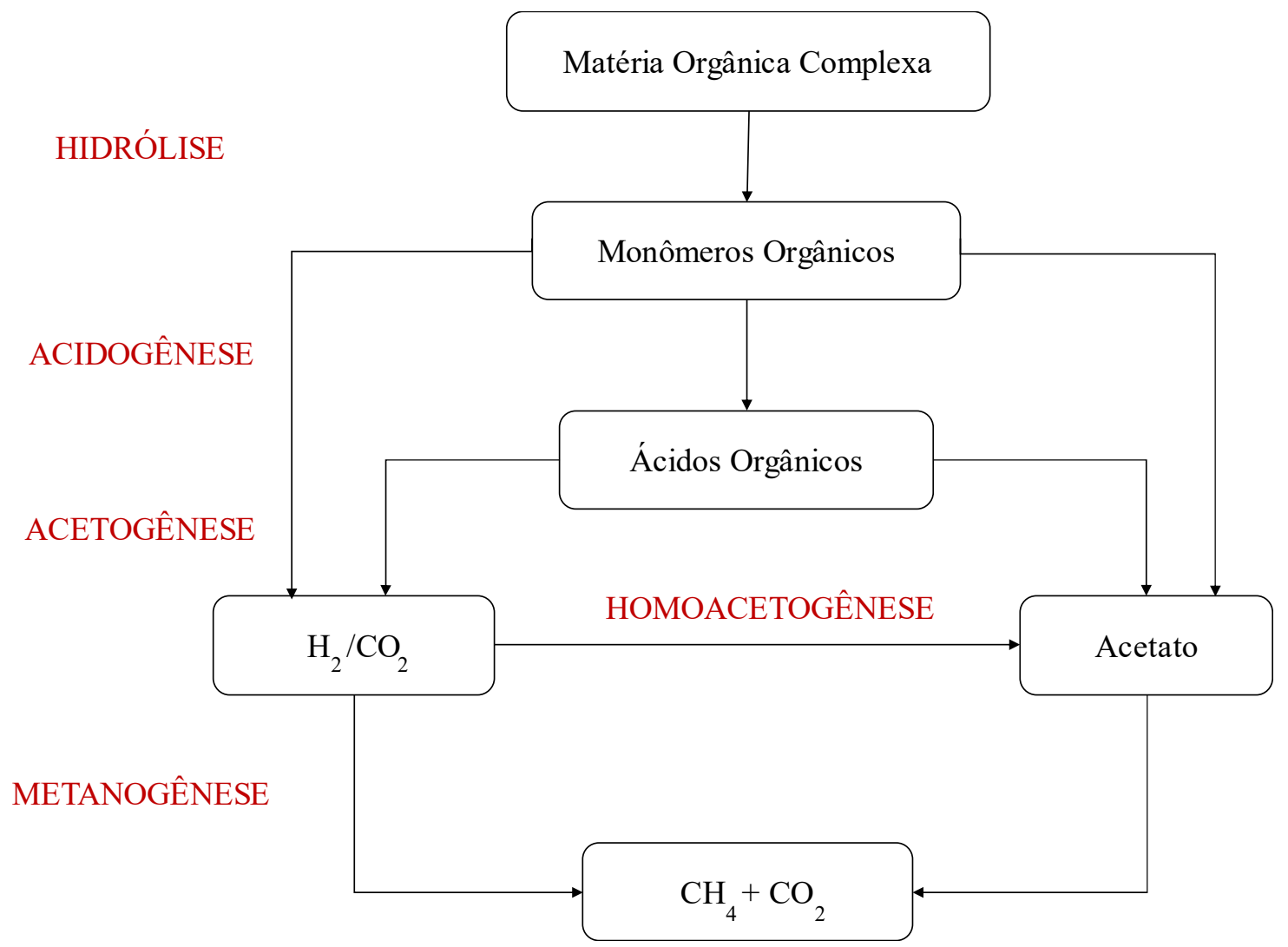

A conversão de $\mathrm{H}_{2}$ e $\mathrm{CO}_{2}$ a metano é realizada pelas arqueias metanogênicas hidrogenotróficas, conforme Equação 4, e a conversão de acetato em metano é realizada pelas arqueias metanogênicas acetoclásticas, conforme Equação 5.

$$
\begin{aligned}
& 4 \mathrm{H}_{2}+\mathrm{CO}_{2} \rightarrow \mathrm{CH}_{4}+2 \mathrm{H}_{2} \mathrm{O} \\
& \mathrm{CH}_{3} \mathrm{COOH} \rightarrow \mathrm{CH}_{4}+\mathrm{CO}_{2}
\end{aligned}
$$$$
\text { (Equação 4) }
$$

A redução do dióxido de carbono $\left(\mathrm{CO}_{2}\right)$ em acetato, apresentada na Figura 3.5, é a homoacetogênese (Drake et al., 2006), realizada por microrganismos acetogênicos autotróficos, que possui reação conforme a Equação 6. 
Conforme pode ser observado pela equação 6, existe o consumo de hidrogênio pelas bactérias homoacetogênicas, gerando uma potencial competição com as metanogênicas hidrogênotróficas pelo $\mathrm{H}_{2}$, conforme equação 4. Devido ao fato de serem consumidoras de hidrogênio, as bactérias homoacetogênicas são tão indesejáveis quanto as metanogênicas hidrogenotróficas em estudos que objetivam a produção de $\mathrm{H}_{2}$ para geração de energia (Saady, 2013). Por outro lado, o acetato é utilizado como substrato para as metanogênicas acetoclásticas, conforme equação 5. Assim, a homoacetogênese pode ser considerada um importante fator de controle para produção balanceada de metano, apesar de ser considerada termodinamicamente desfavorável em ambientes anaeróbios.

As bactérias homoacetogênicas são consideradas pouco investigadas e subestimadas em comparação às acidogênicas e arqueias metanogênicas. Os principais trabalhos que buscam informações sobre a homoacetogênese objetivam entender o fenômeno e buscar inibi-lo em processos que buscam a geração de hidrogênio para geração de energia. São também consideradas mais persistentes pois possuem maior diversidade filogenética e são muito versáteis em diferentes níveis tróficos (Saady, 2013).

Com objetivo de aumentar a produção de acetato a partir de glicose, Nie et al. (2007) desenvolveram um sistema de dois reatores, sendo o primeiro acidogênico e o segundo homoacetogênico. Os reatores eram conectados de forma em que os gases gerados $\left(\mathrm{H}_{2}\right.$ e $\left.\mathrm{CO}_{2}\right)$ no primeiro reator fossem encaminhados para o segundo. Um prétratamento do lodo de inóculo e uma suplementação de nutrientes no reator homoacetogênico promoveu um aumento de $87 \%$ de acetato em relação a um sistema de controle sem tratamento do lodo inóculo. O sistema proposto mostrou ser uma alternativa aos sistemas anaeróbios de duas fases para aproveitamento econômico de acetato.

Zhang et al. (2009) investigaram a aplicação de pré-tratamento de lodo com impulsos elétricos intermitentes em reator metanogênico. Através de análises de sequenciamento, observou-se que os choques elétricos promoveram um aumento da comunidade microbiana, inclusive da espécie Treponema, que é homoacetogênica, e a família Methanosaetaceae se tornou dominante na comunidade de arqueias. Assim, foi observado um aumento de $30 \%$ na produção de metano a partir do lodo que foi 
submetido ao pré-tratamento, mostrando uma rota interessante de associação de homoacetogênese com a metanogênese acetoclástica.

A influência do TDH no controle da metanogênese e da homoacetogênese foi estudada por Si et al. (2015). Foram estudados um reator UASB e um reator de leito fixo com TDH diminuindo gradativamente a partir do valor de $24 \mathrm{~h}$. O reator UASB e o reator de leito fixo apresentaram diminuição significativa da homoacetogênese em TDH de $8 \mathrm{~h}$ e $4 \mathrm{~h}$, respectivamente, mas sem remoção dos microrganismos, uma vez que ao se restaurar um TDH de $12 \mathrm{~h}$ a atividade homoacetogênica se reestabeleceu.

Liu et al. (2016) avaliaram o comportamento de reatores anaeróbios metanogênicos após a adição exógena de $\mathrm{H}_{2}$ e $\mathrm{CO}_{2}$ e concluíram que $40 \%$ do $\mathrm{H}_{2}$ foi prontamente consumido pelas homoacetogênicas e o acetato foi posteriormente pelas metanogênicas acetoclásticas para geração do metano. Dessa forma, observou-se que a comunidade homoacetogênica existente é capaz de converter uma quantidade maior de hidrogênio a acetato quando a quantidade de hidrogênio (pressão parcial de hidrogênio) atinge valores altos correspondentes ao limite máximo de conversão pelas metanogênicas hidrogenotróficas. Além disso, verifica-se que a homoacetogênese não necessariamente se reflete num aumento da concentração de acetato no efluente, uma vez que o mesmo pode ser prontamente convertido em metano.

\subsection{Atividade Metanogênica Específica}

A atividade metanogênica específica (AME) é definida como a capacidade de produção de metano máxima a partir de um consórcio de microrganismos anaeróbios, em condições controladas de laboratório (Aquino et al., 2007). Os testes de AME podem ser realizados para comparar os resultados obtidos nos testes com os resultados obtidos na operação de reator ou para determinação prévia de condições operacionais a serem aplicadas em reator anaeróbio. Além disso, a utilização de teste de AME se torna uma alternativa viável quando comparada com uma caracterização completa de biomassa de um reator, devido aos altos custos e a utilização de equipamentos complexos para classificação e contagem dos microrganismos presentes (Agrawal et al., 1997).

As metodologias dos testes de AME não se encontram padronizadas internacionalmente, dificultando a comparação entre diferentes estudos. No entanto, os 
resultados obtidos nos testes são úteis para a comparação entre determinadas condições e fases operacionais de reatores anaeróbios em um mesmo experimento (Aquino et al., 2007).

\subsection{Considerações}

A partir das informações coletadas na literatura, o trabalho buscou avaliar a viabilidade de utilização da co-digestão em reatores UASB tratando esgoto sanitário, simulando a utilização de glicerol para o aumento da produção de metano em reatores municipais.

Segundo Noyola et al. (2012) a tecnologia de reatores UASB é utilizada em 17\% das ETEs na América Latina, representando um total de 493 reatores tratando 14,2 m³/s. O clima favorável à utilização dessa tecnologia não é acompanhado pelo aproveitamento do metano gerado, muitas vezes pela pequena quantidade produzida em reatores de menor escala.

No Brasil, o aumento de produtores de biodiesel foi proporcionado pelo lançamento do Programa Nacional de Produção e Uso de Biodiesel (PNPB) em 2004, tornando o país o segundo maior produtor do mundo, somente atrás dos EUA (REN21, 2016). Segundo Stattman \& Mol (2014), a criação do Selo Combustível Social pelo Ministério do Desenvolvimento Agrário (MDA) teve como objetivo a inclusão social de pequenos agricultores até a rede de produção de biodiesel. Nesse contexto, também se considerou que o sistema poderia ser uma solução ambiental para o glicerol gerado por pequenos produtores de biodiesel.

Dessa forma, buscou-se estudar essa tecnologia, considerando que a utilização de glicerol como co-substrato é de alta complexidade devido às suas rotas de fermentação. O sistema proposto não é convencional em comparação aos recentes trabalhos de co-digestão no que se refere ao aumento da carga orgânica com substrato fermentável sem correção do $\mathrm{pH}$, bem como devido ao baixo tempo de detenção hidráulica aplicado. 


\section{MATERIAL E MÉTODOS}

\subsection{Esgoto Sanitário}

O esgoto sanitário utilizado no trabalho era obtido de um coletor de esgoto que passa pela Área 2 do Campus Universitário de São Carlos, da Universidade de São Paulo (USP). O coletor passa próximo ao Laboratório de Processos Biológicos da Escola de Engenharia de São Carlos (EESC) e se situa próximo ao local onde o reator foi instalado. As características do esgoto utilizado estão apresentadas na Tabela 4.1, conforme caracterizado por Moura (2014).

Tabela 4.1 - Características do esgoto sanitário a ser utilizado (Fonte: Moura, 2014)

\begin{tabular}{cc}
\hline \multicolumn{2}{c}{ Características do Esgoto Sanitário } \\
\hline Parâmetro & Concentração $(\mathrm{mg} / \mathrm{L})$ \\
\hline DQO & $493 \pm 154$ \\
Alcalinidade & $177,4 \pm 41,5$ \\
$\mathrm{pH}$ & $7,0 \pm 0,2$ \\
$\mathrm{NTK}$ & $45 \pm 13$ \\
$\mathrm{~N}^{-N_{H}}{ }^{+}$ & $31,9 \pm 10,6$ \\
$\mathrm{~N}^{-} \mathrm{NO}_{2}{ }^{-}$ & $0,4 \pm 0,8$ \\
$\mathrm{~N}_{-}-\mathrm{NO}_{3}{ }^{-}$ & $0,5 \pm 1,3$ \\
$\mathrm{P}_{-} \mathrm{PO}_{4}^{-}$ & $4,0 \pm 2,1$ \\
Sólidos Totais & $574,0 \pm 130,6$
\end{tabular}

\subsection{Glicerol}

O glicerol utilizado no presente projeto era resíduo proveniente da indústria Biobrotas Oleoquímica, localizada em Brotas (SP). A DQO do resíduo é de aproximadamente $1.200 .000 \mathrm{mg} / \mathrm{L}$. A 
Figura 4.1 mostra uma foto do glicerol residual utilizado no trabalho, que se trata de um resíduo altamente viscoso e incolor.

Figura 4.1 - Glicerol residual bruto utilizado.



Antes da preparação da água afluente ao reator, foram preparadas soluções de glicerol com água de torneira, com objetivo de padronizar a solução a modo a permitir constante a porcentagem de glicerol a ser aplicada. A solução de glicerol foi preparada 5 vezes durante os 283 dias de operação do reator. A princípio, foi preparada uma solução de $200 \mathrm{~L}$, com a qual se pretendia utilizar completamente até o esgotamento. Porém, foi possível observar que a solução estava em processo fermentativo com diminuição do valor de $\mathrm{pH}$ e aumento da concentração de ácidos. Assim, optou-se por descartar a primeira solução e por se preparar soluções de menor volume, com maior frequência. A Tabela 4.2 mostra as características da solução de glicerol utilizada antes do descarte da primeira solução. Vale ressaltar que as outras soluções foram feitas com a mesma proporção glicerol/água, tendo, portanto, a mesma faixa de DQO.

Tabela 4.2 - Características da primeira solução de glicerol utilizada.

\begin{tabular}{cc}
\hline DQO $(\mathrm{g} / \mathrm{L})$ & 15,98 \\
\hline $\mathrm{pH}$ & 3,52 \\
\hline AVT $(\mathrm{mg} / \mathrm{L})$ & 1283,11
\end{tabular}




\subsection{Reator}

O trabalho foi realizado em um reator anaeróbio de manta de lodo e fluxo ascendente (UASB) que foi alimentado continuamente com a mistura de glicerol e esgoto sanitário. A Figura 4.2 mostra uma foto do reator utilizado no presente trabalho.

Figura 4.2 - Reator UASB.

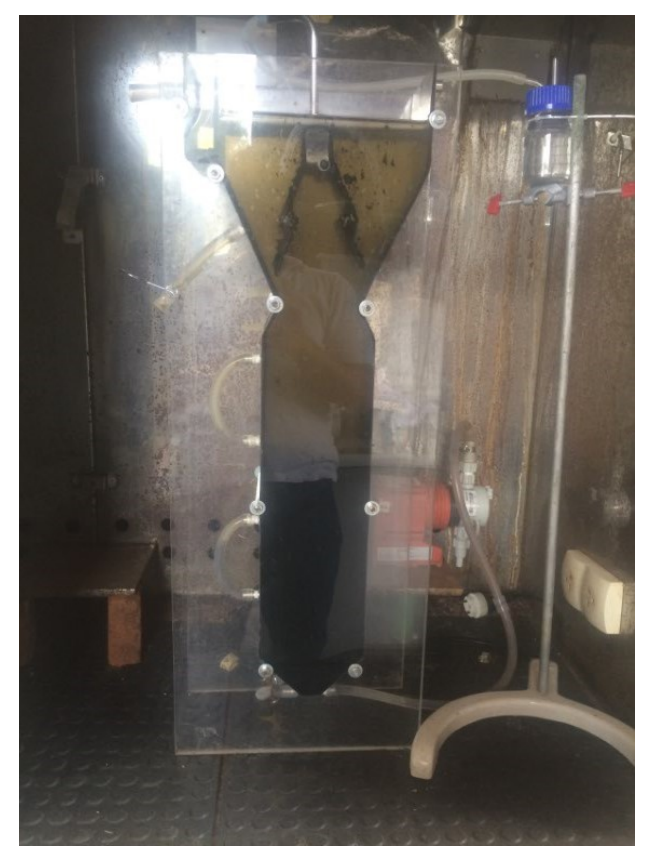

O reator possui altura total de $65 \mathrm{~cm}$ e volume útil de $10 \mathrm{~L}$, separador trifásico triangular e sistema de coleta do efluente através de tubo com furos seguida de calha. $\mathrm{O}$ reator conta com um sistema de coleta de biogás que se encontra na parte superior do superior do separador trifásico, formando um headspace. A alimentação foi realizada por bombeamento do afluente junto à base do reator.

\subsubsection{Partida}

A partida do reator foi realizada pela aplicação direta de esgoto sanitário, uma vez que o mesmo já estava sendo utilizado em outro projeto de pesquisa, alimentado com esgoto do mesmo coletor municipal e operado nas mesmas condições de vazão (tempo de detenção hidráulica de 8 horas). O reator foi previamente inoculado com lodo proveniente de reator UASB tratando efluente de abatedouro de aves. 


\subsubsection{Operação}

O reator foi instalado em câmara climatizada (incubadora de DBO) adaptada para a operação do reator a $25^{\circ} \mathrm{C}$.

O reator foi operado de maneira contínua, com aumento gradual da quantidade de glicerol e com TDH constante de 8 horas. O monitoramento foi realizado a partir das análises apresentadas no tópico 4.3.3 Métodos Analíticos.

\subsubsection{Métodos Analíticos}

As análises de monitoramento realizadas do reator UASB estão apresentadas na Tabela 4.3, assim como suas respectivas frequências e métodos.

Tabela 4.3 - Análises de monitoramento do reator e suas respectivas frequências e métodos

\begin{tabular}{ccc}
\hline Análise & Método & Frequência \\
\hline Vazão & Medição volumétrica & diária \\
DQO & Espectrofotométrico & $3 \times$ semana \\
$\mathrm{pH}$ & Potenciométrico & $3 \times$ semana \\
Produção de biogás & Vazão Volumétrica & diária \\
Composição do biogás & Cromatografia gasosa & 3 x semana \\
Ácidos voláteis & Cromatografia gasosa & $3 \times$ semana \\
Alcalinidade total e bicarbonato & Titulométrico & $3 \times$ semana \\
\hline
\end{tabular}

A caracterização foi realizada no afluente, no efluente e no biogás. Para as amostras líquidas, as análises de demanda química de oxigênio (DQO) e pH foram determinadas conforme os procedimentos descritos no "Standard Methods for the Examination of Water and Wastewater" (APHA, 2005).

A concentração de alcalinidade foi determinada por titulometria seguindo procedimentos descritos no "Standard Methods for the Examination of Water and Wastewater" (APHA, 2005) e o monitoramento foi realizado pela medição de alcalinidade total e alcalinidade a bicarbonato por método apresentado por Ripley et al. (1986). 
As análises de ácidos orgânicos voláteis foram realizadas em cromatógrafo HPLC Shimadzu ${ }^{\circledR}$ modular com sistema de bombeamento (LC-10AD), forno (CTO20A), controlador (SCL-10A) e um fotodetector de matriz de diodo (PDA- Photo Diode Array) ajustado para ler comprimentos de onda entre 190 a $380 \mathrm{~nm}$ (UV) com passo de $1 \mathrm{~nm}$. As concentrações foram expressas pela identificação de picos e a integração pelo software Shimadzu Class-VP®.

A composição do biogás nas amostras gasosas foi determinada por análises de cromatografia gasosa utilizando cromatógrafo do modelo Shimadzu ${ }^{\circledR}$ GC-2010, com uma coluna capilar Carbonex ${ }^{\circledR} 1010(30 \mathrm{~m}$ x 0,53 mm x 0,30 $\mu \mathrm{m})$ e um detector de condutividade térmica (TCD), usando argônio como gás de arraste e ar comprimido sintético como make-up em $12 \mathrm{~mL} / \mathrm{min}$. As temperaturas do injetor e do detector eram de $220^{\circ} \mathrm{C}$ a $230^{\circ} \mathrm{C}$, respectivamente. A temperatura aplicada do forno foi constituída em um programa em rampa inicial de $40^{\circ} \mathrm{C}$ por 2 minutos, seguida de elevação até $60^{\circ} \mathrm{C}$ a uma taxa de $5^{\circ} \mathrm{C} /$ min e então até $95^{\circ} \mathrm{C}$ a $25^{\circ} \mathrm{C} / \mathrm{min}$. A temperatura de $95^{\circ} \mathrm{C}$ era mantida durante 5 minutos até as extremidades de execução. O volume de biogás injetado nas análises era de $50 \mu \mathrm{L}$. Dessa forma, foi possível identificar as concentrações de hidrogênio, nitrogênio, dióxido de carbono e metano presentes na fase gasosa.

A vazão de biogás produzido foi medida por um instrumento MilligasCounter da Ritter®.

\subsection{Atividade metanogênica específica}

A atividade metanogênica específica (AME) foi mensurada durante a $5^{\text {a }}$ fase operacional do reator, com intuito de avaliar a eficiência do reator em relação ao teste com condições pré-determinadas.

O teste foi realizado a partir do kit Oxitop ${ }^{\circledR}$, que usualmente é empregado em determinações de demanda bioquímica de oxigênio (DBO), através de medições de pressão de oxigênio e dióxido de carbono na fase gasosa. O sistema Oxitop ${ }^{\circledR}$ é constituído por um frasco de vidro com duas aberturas laterais e um "cabeçote", onde são realizadas as medições de pressão. O sistema é selado por um septo de borracha e por uma válvula de teflon hermético.

Para a realização do teste do AME, foi utilizada uma adaptação do sistema Oxitop ${ }^{\circledR}$, conforme metodologia desenvolvida por Martins (2015). Durante os testes, os 
frascos foram mantidos em estufa sob temperatura controlada $\left(30^{\circ} \mathrm{C}\right)$ e agitação $(200$ rpm). Os cabeçotes de medição registravam a sobrepressão gerada devido à acumulação de biogás no headspace automaticamente. Dessa forma, o cálculo da AME foi realizado a partir do equipamento de leitura do sistema, considerando o volume do headspace, temperatura e equação de gases ideais.

O ensaio de AME foi realizado a partir do lodo que foi coletado através do fundo do reator. $\mathrm{O}$ ensaio foi realizado em triplicata, onde foram adicionados $22,7 \mathrm{~g}$ de lodo e completando até $100 \mathrm{~mL}$ com água destilada. Dessa forma, a concentração de SV nos testes foi de $5 \mathrm{~g} / \mathrm{L}$.

Foram adicionados $100 \mu \mathrm{L}$ da solução de macro e micronutrientes, além de soluções de ácidos orgânicos. A composição das soluções de macro e micronutrientes está apresentada na Tabela 4.4.

Tabela 4.4 - Soluções de macro e micronutrientes utilizadas nos testes de AME.

\begin{tabular}{cc}
\hline \multicolumn{2}{c}{ Macronutrientes $(\mathrm{mg} / \mathrm{L})$} \\
\hline $\mathrm{NH}_{4} \mathrm{Cl}$ & 73,6 \\
$\mathrm{KH}_{2} \mathrm{PO}_{4}$ & 13,3 \\
$\left(\mathrm{NH}_{4}\right)_{2} \mathrm{SO}_{4}$ & 13,3 \\
\hline $\mathrm{Micronutrientes}(\mathrm{mg} / \mathrm{mL})$ \\
\hline $\mathrm{FeCl}_{2} \cdot 4 \mathrm{H}_{2} \mathrm{O}$ & 2000 \\
$\mathrm{CoCl}_{2} \cdot 6 \mathrm{H}_{2} \mathrm{O}$ & 2000 \\
$\mathrm{MnCl}_{2} \cdot 4 \mathrm{H}_{2} \mathrm{O}$ & 500 \\
$\mathrm{CuCl}_{2} \cdot 2 \mathrm{H}_{2} \mathrm{O}$ & 30 \\
$\left(\mathrm{NH}_{4}\right)_{6} \cdot \mathrm{Mo}_{7} \cdot \mathrm{O}_{24} .4 \mathrm{H}_{2} \mathrm{O}$ & 50 \\
$\mathrm{NiCl}_{2} \cdot 6 \mathrm{H}_{2} \mathrm{O}$ & 10 \\
$\mathrm{ZnCl}_{2} \cdot \mathrm{H}_{2} \mathrm{O}$ & 50 \\
$\mathrm{H}_{3} \mathrm{PO}_{3}(\mathrm{saturada})$ & $1 \mathrm{~mL}$ \\
\hline
\end{tabular}

Como fonte de carbono do teste foi utilizado $1 \mathrm{~mL}$ de solução de ácido acético, propiônico e butírico. A utilização desses ácidos orgânicos voláteis permite a quantificação da atividade metanogênica dos grupos acetoclásticos e hidrogenotróficos, a partir do sintrofismo de microrganismos consumidores e produtores de acetato (Aquino et al., 2007). 


\section{RESULTADOS E DISCUSSÃO}

\subsection{Carga Orgânica Volumétrica (COV)}

$\mathrm{O}$ experimento contou com seis fases operacionais sequenciais, diferenciadas pela concentração de glicerol adicionado à alimentação com esgoto sanitário. O avanço de fases foi realizado conforme o reator apresentasse certa estabilidade operacional. Os valores médios de COV aplicada ao reator em cada fase estão apresentados na Tabela 5.1 e a variação temporal dos valores aplicados está apresentada na Figura 5.1.

Tabela 5.1 - Valores médios de COV ao longo das fases operacionais.

\begin{tabular}{ccccc}
\hline $\begin{array}{c}\text { Fase } \\
\text { operacional }\end{array}$ & \multicolumn{2}{c}{$\operatorname{COV}\left(\mathrm{kgDQO} / \mathrm{m}^{3}\right.$ dia $)$} & $\begin{array}{c}\text { Tempo de } \\
\text { operação (dias) }\end{array}$ \\
\hline 1 & 1,74 & \pm & 0,25 & 57 \\
2 & 2,43 & \pm & 0,26 & 46 \\
3 & 4,03 & \pm & 0,72 & 52 \\
4 & 5,24 & \pm & 0,41 & 75 \\
5 & 5,68 & \pm & 0,59 & 35 \\
6 & 6,92 & \pm & 0,57 & 18 \\
\hline
\end{tabular}

Figura 5.1 - Variação temporal dos valores de COV aplicados.

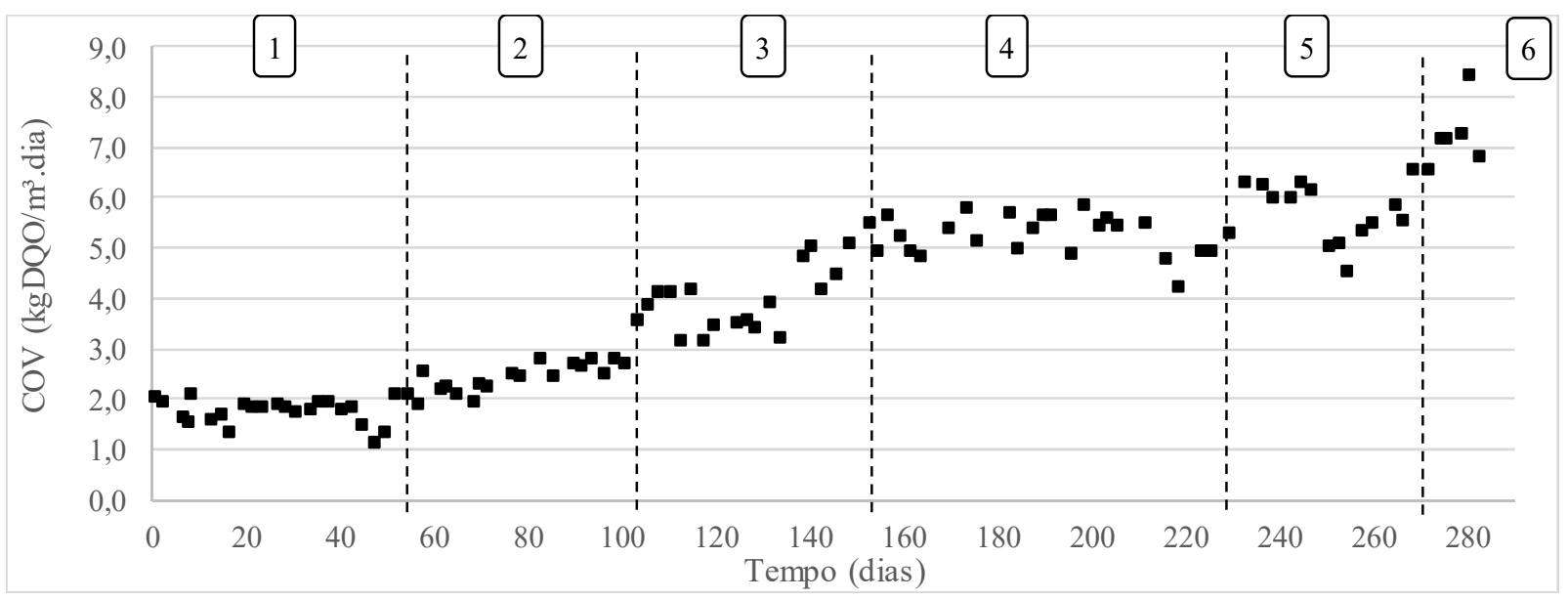


A variação de valores de COV dentro de cada fase operacional observada na Figura 5.1 e na Tabela 5.1 se deu por dois fatores: a variação natural da qualidade do esgoto sanitário e pela alta concentração de DQO da solução de glicerol utilizada.

A Figura 5.2 mostra um gráfico na forma "box-plot" dos valores de COV aplicados em cada fase. Pode-se observar que houve uma tendência de maior variação conforme o aumento da carga aplicada, evidenciando a dificuldade para promover uma diluição precisa do glicerol.

Figura 5.2 - Gráfico box-plot dos valores de COV aplicados.

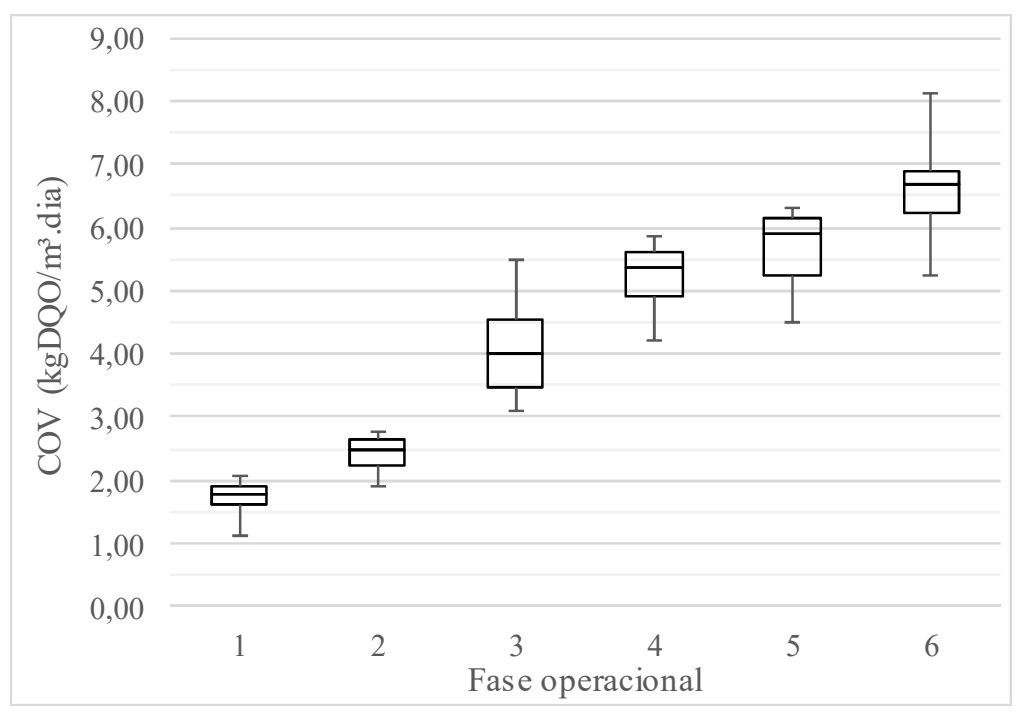

Em comparação com os dados apresentados na Tabela 3.1 e da Tabela 5.3, verifica-se que diversos estudos disponíveis na literatura sobre co-digestão com glicerol apresentaram COV de colapso em valores abaixo dos aplicados no presente trabalho.

\subsection{DQO}

\subsubsection{DQO bruta}

A variação de DQO afluente aplicada ao reator foi a variável de referência para o avanço das fases do trabalho, uma vez que a vazão era constante para que se pudesse manter o tempo de detenção hidráulico de 8 horas. Dessa forma, a vazão de bombeamento se manteve constante em $20,8 \mathrm{~mL} / \mathrm{min}$. 
A Tabela 5.2 mostra os valores médios de DQO bruta afluente e efluente de cada fase, assim como os seus respectivos valores médios de eficiência de remoção.

Tabela 5.2 - Valores médios de DQO afluente e efluente ao longo das fases operacionais.

\begin{tabular}{cccccccccc}
\hline $\begin{array}{c}\text { Fase } \\
\text { operacional }\end{array}$ & $\begin{array}{c}\text { COV } \\
\left(\mathrm{kgDQO} / \mathrm{m}^{3} \mathrm{dia}\right)\end{array}$ & \multicolumn{3}{c}{ Afluente $(\mathrm{mg} / \mathrm{L})$} & & Efluente $(\mathrm{mg} / \mathrm{L})$ & $\begin{array}{c}\text { Eficiência de } \\
\text { remoção (\%) }\end{array}$ \\
\hline 1 & 1,74 & 581 & \pm & 83 & 155 & \pm & 48 & $73 \%$ \\
2 & 2,43 & 811 & \pm & 87 & 220 & \pm & 107 & $73 \%$ \\
3 & 4,03 & 1346 & \pm & 239 & 238 & \pm & 76 & $81 \%$ \\
4 & 5,24 & 1750 & \pm & 142 & 170 & \pm & 56 & $90 \%$ \\
5 & 5,68 & 1895 & \pm & 196 & 276 & \pm & 124 & $85 \%$ \\
6 & 6,92 & 2311 & \pm & 190 & 470 & \pm & 66 & $80 \%$ \\
\hline
\end{tabular}

A partir da Tabela 5.2, pode-se observar que a eficiência de remoção de DQO apresentou valores de $90 \%, 85 \%$ e $80 \%$ nas fases 4,5 e 6 , respectivamente. As fases 1 , 2 e 3 apresentaram valores respectivos de $73 \%, 73 \%$ e $81 \%$, indicando uma menor eficiência percentual de remoção de DQO quando a carga aplicada era menor. As maiores eficiências nas fases com maior COV aplicada pode ter sido influenciada pelo período de adaptação dos microrganismos e pelo aproveitamento dos nutrientes presentes no esgoto com a carga do glicerol no processo co-digestivo. Além disso, a resistência à transferência entre massa entre biofilme e substrato foi superada por um provável aumento do grau de mistura no reator devido à maior produção de biogás.

Tendo em vista os valores absolutos, observa-se que houve o aumento dos valores de DQO efluente média, de acordo com a Tabela 5.2. O aumento desses valores absolutos de DQO efluente se dá naturalmente pelo fato de que o aumento da DQO aplicada acarretou também no aumento de matéria não-biodegradável no reator.

Os resultados apresentados na Tabela 5.2 - Valores médios de DQO afluente e efluente ao longo das fases operacionais. são similares aos obtidos por Nuchdang \& Phalakornkule (2012) em trabalho sobre tratamento anaeróbio de glicerol com esterco de porco. Os autores observaram remoção de DQO acima de $80 \%$ mesmo nas condições mais críticas onde foi constatada diminuição da produção de metano e acúmulo de ácidos orgânicos. O pequeno tempo de operação na condição mais crítica do trabalho citado (cerca de 5 dias) e do presente trabalho (18 dias na $6^{\text {a }}$ fase operacional) pode 
explicar as altas eficiências de remoção de DQO mesmo em condições críticas, deixando de apresentar os dados operacionais após desestabilização dos reatores.

Em termos de COV aplicada e remoção de DQO, a utilização de esgoto sanitário como co-substrato se mostrou melhor que a utilização de lodo de ETE em reatores de co-digestão com glicerol. Zahedi et al. (2018) obtiveram valores inferiores aos observados no presente trabalho, sendo que a eficiência de remoção de DQO bruta foi de aproximadamente $65 \%, 20 \%$ e de $4-10 \%$ para valores de COV de 2,03, 2,89 e 4,89 $\mathrm{kgDQO} / \mathrm{m}^{3}$.dia. Athanasoulia et al. (2014) observaram desestabilização do reator para COV acima de valores de $1,7 \mathrm{kgDQO} / \mathrm{m}^{3}$.dia. Baba et al. (2013) observaram remoção de DQO de 39,1\% com COV de 1,48 $\mathrm{kgDQO} / \mathrm{m}^{3}$.dia. A baixa eficiência apresentada no trabalho citado mostra a dificuldade de aplicação do processo em digestores reais de ETEs, uma vez que o trabalho foi realizado em reator em escala plena.

A Tabela 5.3 apresenta um levantamento de valores observados na literatura em trabalhos de co-digestão anaeróbia com glicerol.

Tabela 5.3 - Levantamento de valores de remoção de DQO e tempos de detenção hidráulica em trabalhos de co-digestão anaeróbia com glicerol.

\begin{tabular}{|c|c|c|c|c|}
\hline Referência & Co-substrato & $\begin{array}{c}\mathrm{COV} \\
\left(\mathrm{kgDQO} / \mathrm{m}^{3} \cdot \mathrm{dia}\right)\end{array}$ & $\mathrm{TDH}$ & Remoção DQO \\
\hline Baba et al. (2013) & Lodo ETE & 1,48 & $(*)$ & $39,1 \%$ \\
\hline \multirow{2}{*}{$\begin{array}{c}\text { Nuchdang \& } \\
\text { Phalakornkule (2012) }\end{array}$} & \multirow{2}{*}{ Esterco suíno } & 1,30 a 1,70 & $4 \mathrm{~d}$ & $>90 \%$ \\
\hline & & 2,9 a 5,0 & $2 \mathrm{a} 1 \mathrm{~d}$ & $>80 \%$ \\
\hline $\begin{array}{l}\text { Athanasoulia et al. } \\
\text { (2014) }\end{array}$ & Lodo ETE & 1,0 a 1,70 & $\begin{array}{l}12,3 \mathrm{a} \\
19,7 \mathrm{~d}\end{array}$ & $>85 \%$ \\
\hline \multirow[t]{2}{*}{$\begin{array}{l}\text { Rodríguez-Abalde et al. } \\
\qquad(2017)\end{array}$} & $\begin{array}{c}\text { Resíduo de abatedouro } \\
\text { de aves }+ \text { Estrume de } \\
\text { porco }\end{array}$ & 3,2 & $33 d$ & $51 \%$ \\
\hline & & 2,03 & $9 \mathrm{~d}$ & $60-65 \%$ \\
\hline \multirow[t]{2}{*}{ Zahedi et al. (2018) } & Lodo ETE & 2,89 & $7 \mathrm{~d}$ & $14-20 \%$ \\
\hline & & 4,05 & $5 \mathrm{~d}$ & $4-10 \%$ \\
\hline
\end{tabular}

(*): valor não apresentado.

Conforme evidenciado na Tabela 5.3, existe uma grande diferença entre o TDH aplicado no presente trabalho e dos trabalhos encontrados na literatura e, por outro lado, as COVs aplicadas são da mesma ordem de grandeza. Tal fato se dá porque os valores 
absolutos de DQO aplicada são maiores nos dados da literatura, onde se objetivou a produção de metano em reatores análogos a biodigestores anaeróbios de lodo, enquanto que, nesta pesquisa, se buscou simular um reator tratando esgoto sanitário. A eficiência maior observada no menor TDH pode ter sido influenciada pela velocidade de escoamento dentro do reator, por diminuir a resistência à transferência de massa entre biofilme e substrato, além de proporcionar a quebra do substrato pela hidrólise. A maior variedade nutricional do esgoto sanitário em relação aos outros co-substratos também pode ter influenciado na maior eficiência no reator.

A Figura 5.3 mostra o perfil dos valores de DQO bruta afluente e efluente ao longo da operação do reator.

Figura 5.3 - Variação dos valores de DQO afluente e efluente.

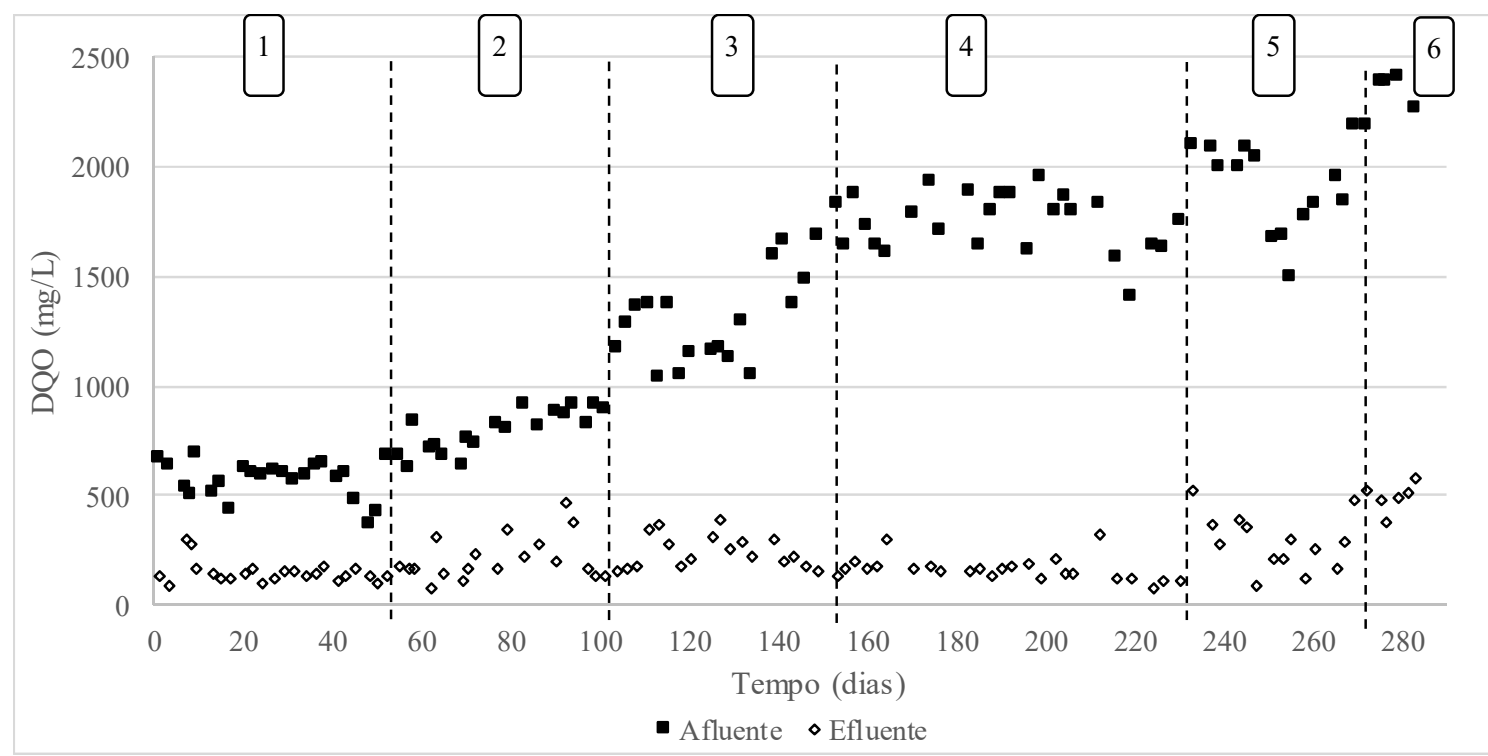

A partir da Figura 5.3, que mostra a variação de DQO afluente e efluente podese observar diferentes comportamentos do reator a partir do avanço de fases. Após o aumento da COV aplicada nas fases 2, 3, 5 e 6 o reator apresentou certa instabilidade, evidenciada nos valores de DQO efluente. Já na fase 4, com COV de 5,24 $\mathrm{kgDQO} / \mathrm{m}^{3}$.dia, o reator não apresentou instabilidade e manteve-se com DQO efluente abaixo de $200 \mathrm{mg} / \mathrm{L}$ ao longo de toda a fase, chegando a apresentar valores abaixo de $120 \mathrm{mg} / \mathrm{L}$ nos últimos 15 dias de operação, mostrando melhor adaptação do reator nesta fase.

A instabilidade apresentada nas fases 2 e 3 pode ser atribuída ao tempo de adaptação da comunidade microbiana à nova característica do afluente, que passou a 
conter glicerol em sua composição. Os valores observados na fase 4 podem evidenciar uma adaptação dos microrganismos com a mistura esgoto com glicerol, após 150 dias de operação, e podem indicar um bom balanço nutricional. Apesar da remoção global média de $85 \%$ para a fase 5 e de $80 \%$ para a fase 6 , o reator passou a apresentar indícios de sobrecarga orgânica, com valores de DQO efluente que iam de abaixo de $200 \mathrm{mg} / \mathrm{L}$ na fase 4, para valores médios de $270 \mathrm{mg} / \mathrm{L}$ e $470 \mathrm{mg} / \mathrm{L}$ nessas fases. A sobrecarga orgânica também pode ser evidenciada pela observação de outros parâmetros físicoquímicos observados nos itens posteriores. Os valores observados na $6^{\mathrm{a}}$ fase de operação aumentaram significativamente mostrando que o reator já estava com tendência ao colapso por sobrecarga orgânica.

A Figura 5.4 mostra um gráfico box-plot dos valores de eficiência de remoção de DQO para as 6 fases operacionais.

Figura 5.4 - Gráfico box-plot dos valores de eficiência de remoção de DQO.

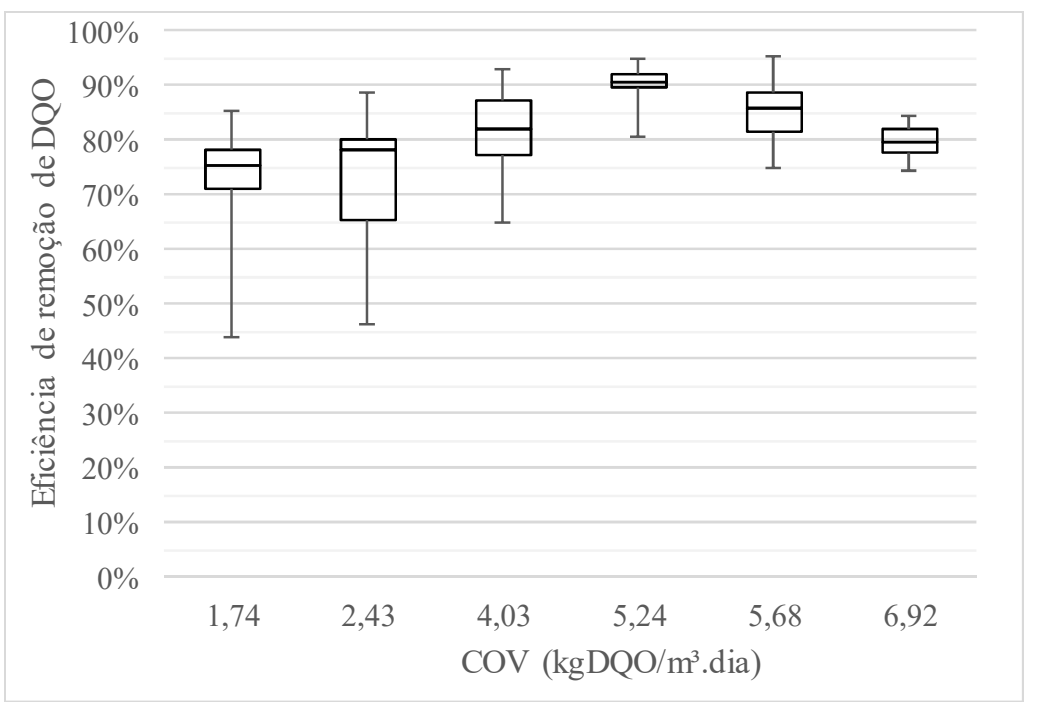

Conforme pode ser observado na Figura 5.4, a fase $n^{\circ} 4$ (COV correspondente de $5,24 \mathrm{kgDQO} / \mathrm{m}^{3}$.dia) foi a que apresentou a maior estabilidade e os maiores valores de eficiência de remoção de DQO, evidenciando também a melhor condição de adaptação dos microrganismos à co-digestão. A perda de eficiência na última fase mostra indícios de sobrecarga orgânica, evidenciada também pelos tópicos posteriores. 


\subsubsection{DQO filtrada}

A Tabela 5.4 mostra os valores médios de DQO filtrada afluente e efluente observados durante as fases de operação, assim como suas respectivas eficiências de remoção.

Tabela 5.4 - Valores médios de DQO Filtrada afluente e efluente ao longo das fases operacionais.

\begin{tabular}{ccccccccc}
\hline $\begin{array}{c}\text { Fase } \\
\text { operacional }\end{array}$ & $\begin{array}{c}\text { COV } \\
\left(\mathrm{kgDQO} / \mathrm{m}^{3} \mathrm{dia}\right)\end{array}$ & \multicolumn{4}{c}{ Afluente $(\mathrm{mg} / \mathrm{L})$} & \multicolumn{2}{c}{ Efluente $(\mathrm{mg} / \mathrm{L})$} & \multicolumn{2}{c}{$\begin{array}{c}\text { Eficiência de } \\
\text { remoção (\%) }\end{array}$} \\
\hline 1 & 1,74 & 238 & \pm & 112 & 105 & \pm & 25 & $51 \%$ \\
2 & 2,43 & 374 & \pm & 104 & 137 & \pm & 64 & $64 \%$ \\
3 & 4,03 & 551 & \pm & 108 & 190 & \pm & 75 & $66 \%$ \\
4 & 5,24 & 409 & \pm & 142 & 126 & \pm & 48 & $68 \%$ \\
5 & 5,68 & 548 & \pm & 82 & 121 & \pm & 106 & $79 \%$ \\
6 & 6,92 & 639 & \pm & 32 & 356 & \pm & 69 & $44 \%$ \\
\hline
\end{tabular}

Conforme evidenciado na Tabela 5.4, os valores de eficiência de remoção foram crescentes até a fase operacional $n^{0} 5$, indo de $51 \%$ a $79 \%$. Já na fase 6 , a eficiência caiu significativamente para o valor de $44 \%$, mostrando que o reator passou a apresentar instabilidade operacional.

A Figura 5.5 mostra a variação temporal dos valores de DQO filtrada afluente e efluente ao longo da operação do reator.

Figura 5.5 - Variação dos valores de DQO Filtrada afluente e efluente.

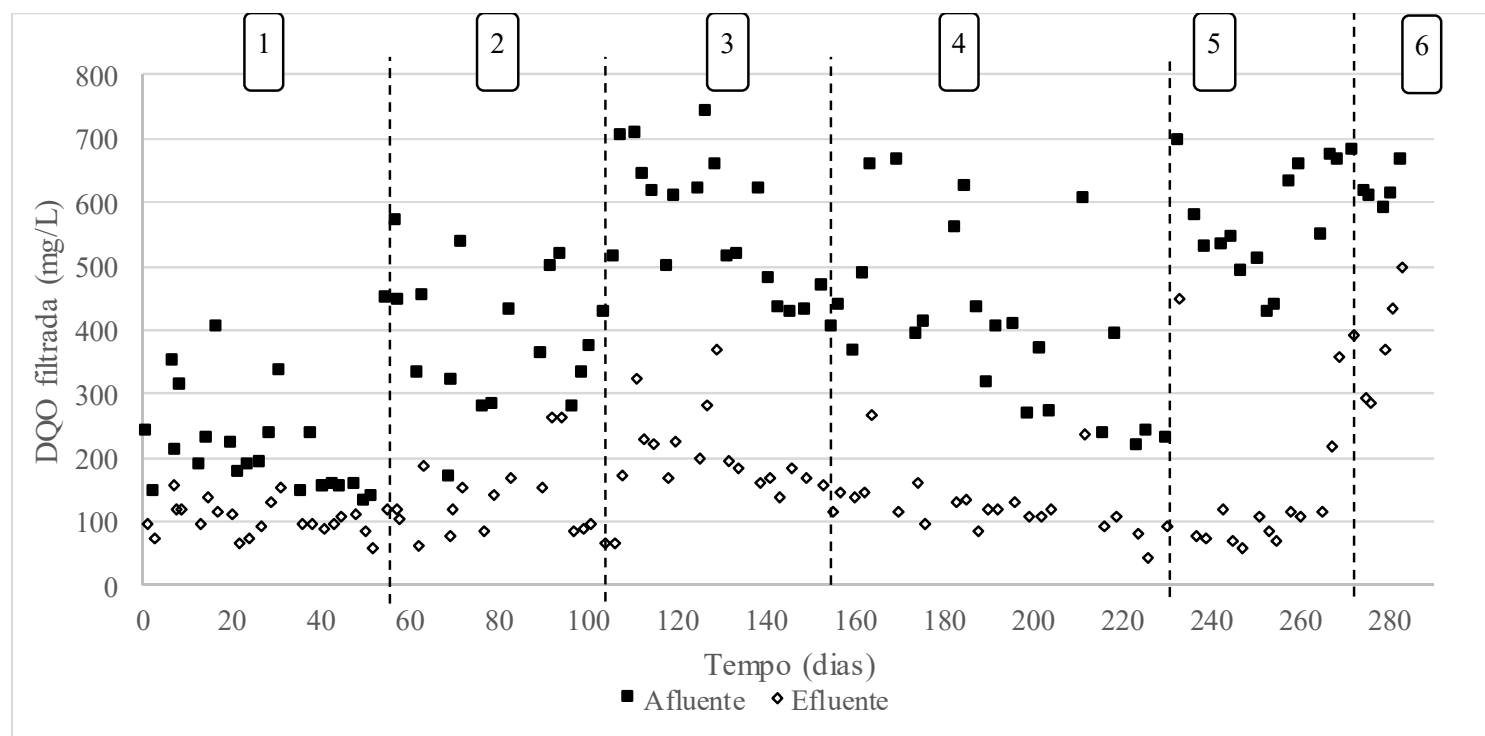


De acordo com a Figura 5.5, os valores de DQO filtrada efluente não sofreram decréscimo conforme o avanço de fases até a fase $n^{\circ} 4$. Além disso, observa-se que os valores de DQO efluente filtrada foram decrescentes dentro de cada fase, mostrando adaptação do reator a cada aumento de COV aplicada.

$\mathrm{Na}$ última fase, observa-se um aumento gradual do valor de DQO filtrada efluente, indo de $217 \mathrm{mg} / \mathrm{L}$ no dia 267 até $498 \mathrm{mg} / \mathrm{L}$ no dia 283, mostrando outro indício de instabilidade operacional nessa fase. Em comparação com os dados apresentados na Figura 5.3 e na Tabela 5.2, observa-se que não houve perda gradual de eficiência de remoção de DQO bruta. Tal fato evidencia que o reator passou a perder, inicialmente, a sua eficiência devido à menor capacidade de conversão de SSV.

A Figura 5.6 mostra um gráfico box-plot dos valores de eficiência de remoção de DQO filtrada ao longo das seis fases operacionais.

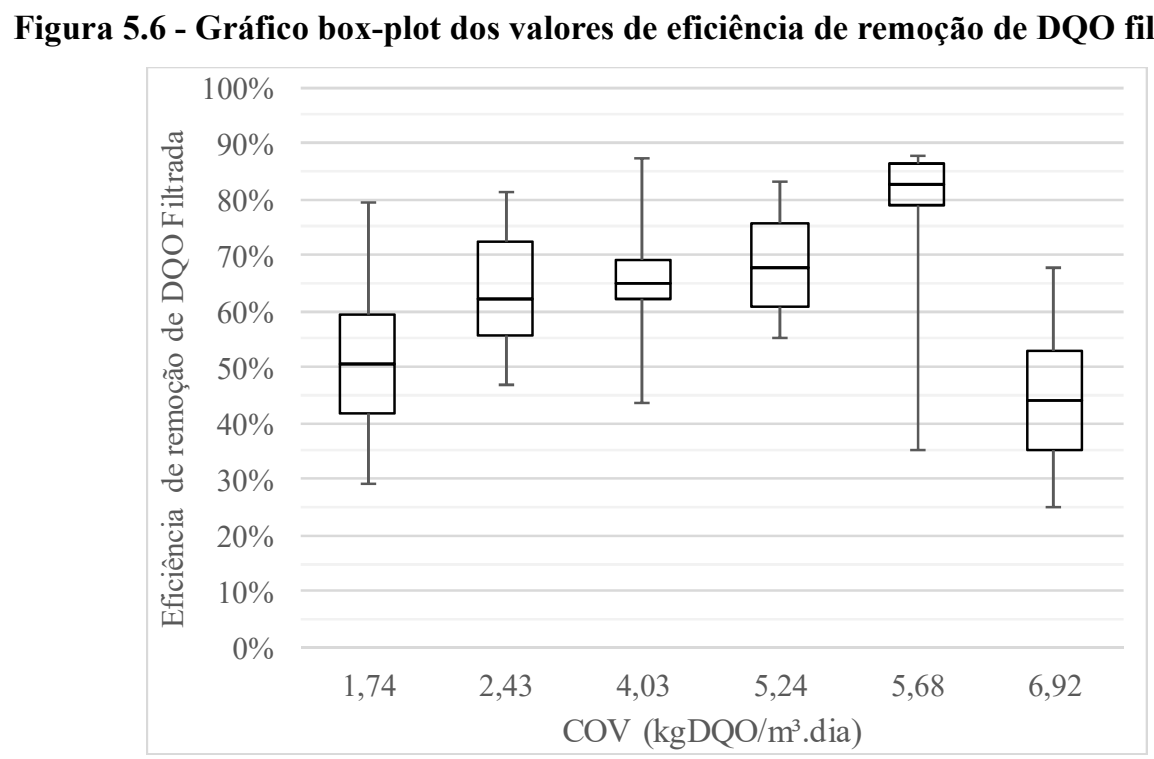

Conforme apresentado na Tabela 5.4, Figura 5.5 e na Figura 5.6, a eficiência de remoção de DQO filtrada foi inferior à eficiência de remoção de DQO bruta em todas as fases operacionais. Observa-se também que houve uma maior variação de valores dentro de cada fase. Esses fatores se dão pela variação de valores de concentração de sólidos suspensos no esgoto sanitário, assim como a capacidade de retenção dos sólidos por sedimentação de reatores UASB. 


\section{3. pH e alcalinidade}

A Tabela 5.5 mostra os valores médios de $\mathrm{pH}$ afluente e efluente ao longo das seis fases operacionais e a Figura 5.7 mostra a variação temporal dos valores de $\mathrm{pH}$ afluente e efluente. Ressalta-se que não houve controle de $\mathrm{pH}$ com adição de álcali em qualquer fase operacional.

Tabela 5.5 - Valores médios de pH afluente e efluente ao longo das fases operacionais.

\begin{tabular}{ccccccccc}
\hline Fase & $\begin{array}{c}\text { COV } \\
\left(\mathrm{kgDQO} / \mathrm{m}^{3} \mathrm{dia}\right)\end{array}$ & \multicolumn{3}{c}{$\mathrm{pH}$ afluente } & \multicolumn{3}{c}{$\mathrm{pH}$ efluente } \\
& 1,74 & 7,39 & \pm & 0,27 & 7,63 & \pm & 0,20 \\
2 & 2,43 & 6,87 & \pm & 0,52 & 7,36 & \pm & 0,35 \\
3 & 4,03 & 7,01 & \pm & 0,55 & 7,36 & \pm & 0,46 \\
4 & 5,24 & 6,98 & \pm & 0,31 & 7,38 & \pm & 0,19 \\
5 & 5,68 & 5,84 & \pm & 0,27 & 6,78 & \pm & 0,27 \\
6 & 6,92 & 5,48 & \pm & 0,25 & 5,90 & \pm & 0,28 \\
\hline
\end{tabular}

Figura 5.7- Variação de valores de $\mathrm{pH}$ afluente e efluente.

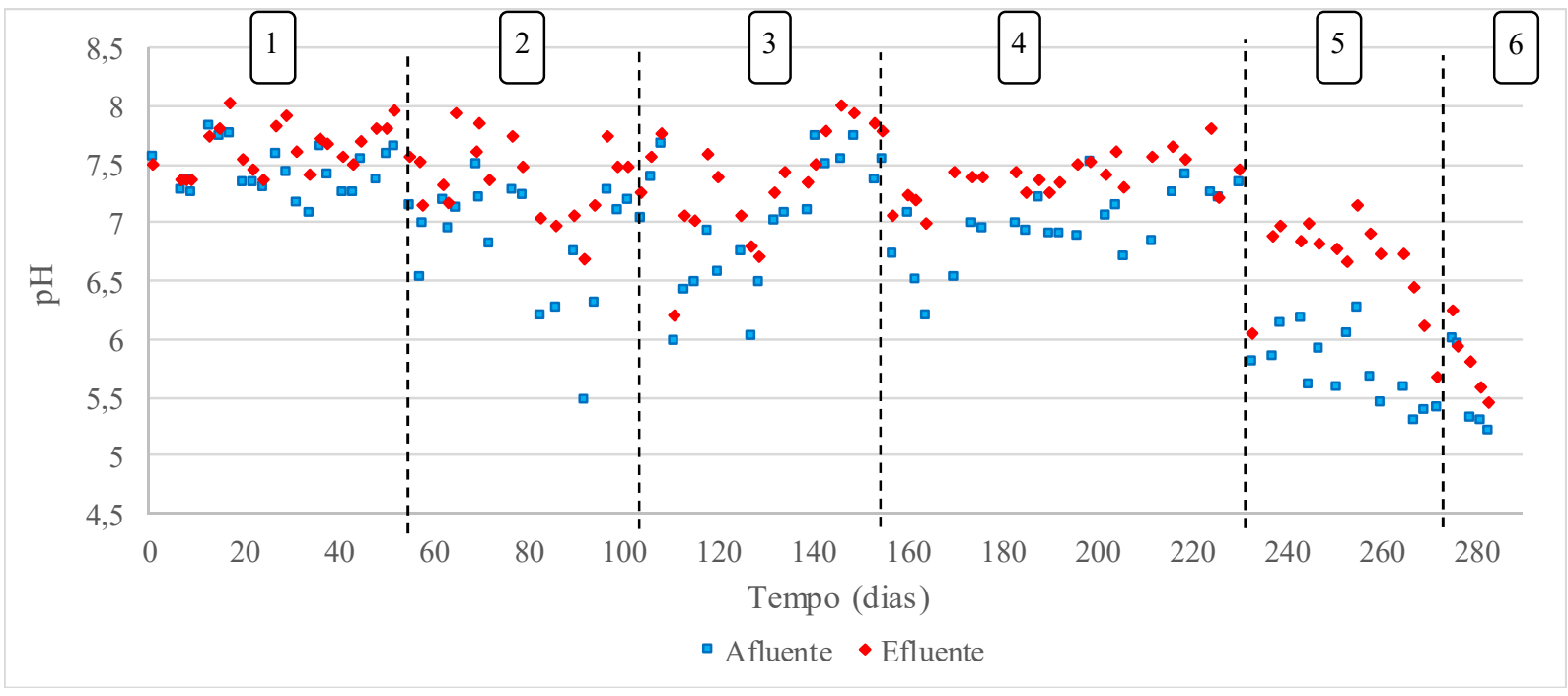

Conforme evidenciado na Tabela 5.5 e na Figura 5.7, os valores de $\mathrm{pH}$ afluente tendiam a diminuir conforme o avanço de fases. A diminuição dos valores de $\mathrm{pH}$ já era esperada, uma vez que, com o aumento da quantidade de glicerol aplicada ao tanque de alimentação, também se esperava um aumento na concentração de ácidos orgânicos aplicados, que seriam naturalmente gerados a partir da fermentação do próprio glicerol dentro do tanque de alimentação. $O$ tanque de alimentação do reator permanecia sempre tampado, era conservado em temperatura ambiente e a solução era produzida em 
intervalos de 3 a 4 dias, a partir da solução de glicerol e de esgoto sanitário coletado diretamente da rede coletora municipal.

A partir da Figura 5.7 verifica-se também que os valores de $\mathrm{pH}$ efluente na $6^{\mathrm{a}}$ fase de operação estavam diminuindo significativamente a cada dia de operação (de 6,43 no dia 267 até 5,45 no dia 283 ), mostrando que o reator havia perdido o equilíbrio metabólico e tendia ao colapso por sobrecarga orgânica e acúmulo de ácidos. O decaimento gradual de $\mathrm{pH}$ também foi observado por Zahedi et al. (2018) em codigestão de glicerol com lodo de ETE em COV aplicada de 4,89 $\mathrm{kgDQO} / \mathrm{m}^{3}$.dia. O mesmo comportamento foi observado por Fountoulakis et al. (2010) para adição de 3\% de glicerol em reator contínuo tratando lodo de ETE.

Observa-se também que os valores de $\mathrm{pH}$ efluente, com exceção da $6^{\mathrm{a}}$ fase, estiveram predominantemente acima dos valores de $\mathrm{pH}$ afluente, conforme esperado para processos anaeróbios tratando esgoto sanitário. As principais causas do aumento do $\mathrm{pH}$ dentro de um reator se dão pelo aumento da alcalinidade total gerada a partir da redução de proteínas (compostos nitrogenados), pela redução de sulfatos e sulfetos e a consequente geração de íons bicarbonato (Speece, 1996).

A Tabela 5.6 mostra os valores médios de alcalinidade total afluente e efluente das seis fases operacionais e a Figura 5.8 mostra a variação temporal dos valores de alcalinidade total.

Tabela 5.6 - Valores médios de alcalinidade afluente e efluente.

\begin{tabular}{|c|c|c|c|c|c|c|c|}
\hline \multirow{3}{*}{$\begin{array}{c}\text { Fase } \\
1\end{array}$} & \multirow{3}{*}{$\begin{array}{c}\mathrm{COV} \\
\left(\mathrm{kgDQO} / \mathrm{m}^{3} \mathrm{dia}\right) \\
1,74\end{array}$} & \multicolumn{6}{|c|}{ Alcalinidade total } \\
\hline & & \multicolumn{3}{|c|}{ Afluente $\left(\mathrm{mgCaCO}_{3} / \mathrm{L}\right)$} & \multicolumn{3}{|c|}{ Efluente $\left(\mathrm{mgCaCO}_{3} / / \mathrm{L}\right)$} \\
\hline & & 110,23 & \pm & 15,44 & 105,24 & \pm & 7,77 \\
\hline 2 & 2,43 & 96,85 & \pm & 16,46 & 96,84 & \pm & 16,04 \\
\hline 3 & 4,03 & 92,97 & \pm & 13,56 & 88,09 & \pm & 11,70 \\
\hline 4 & 5,24 & 86,32 & \pm & 10,58 & 89,81 & \pm & 9,33 \\
\hline 5 & 5,68 & 56,64 & \pm & 5,51 & 71,02 & \pm & 8,31 \\
\hline 6 & 6,92 & 56,95 & \pm & 5,40 & 49,00 & \pm & 4,13 \\
\hline
\end{tabular}


Figura 5.8 - Variação de valores de alcalinidade afluente e efluente.

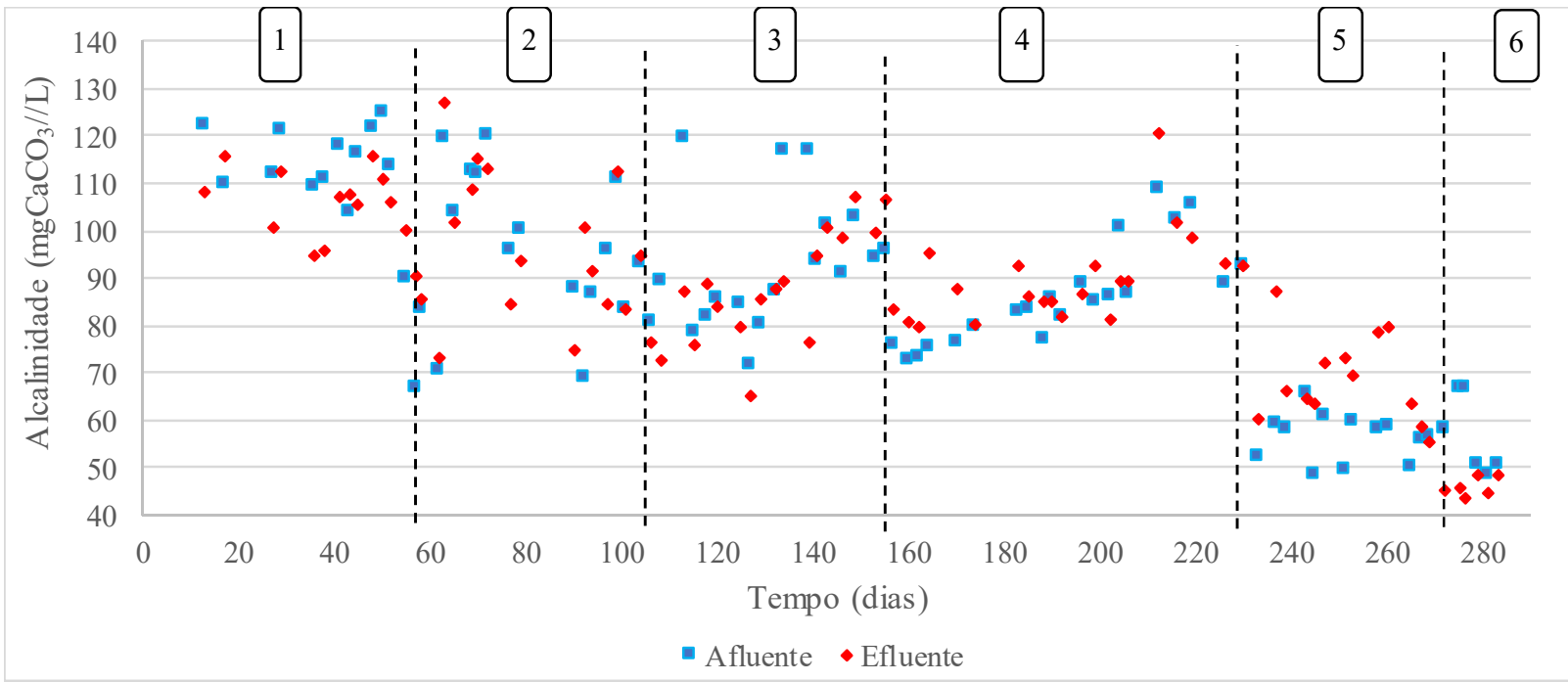

De acordo com a Tabela 5.6 e a Figura 5.8, evidencia-se que os valores de alcalinidade total afluente tendiam a diminuir com o aumento da COV aplicada. Tal fato se explica pelo aumento da concentração de glicerol afluente, que acarretava em uma maior concentração de ácidos orgânicos aplicados, evidenciando a baixa capacidade tampão do esgoto.

A adição de álcali no tanque de alimentação de reator tornaria as condições de operação mais próximas das ideais para um reator anaeróbio, porém optou-se pela não aplicação para não se desviar da proposta tecnológica envolvida no escopo do trabalho, uma vez que a aplicação de alcalis acarretaria num maior custo de operação em uma ETE.

$\mathrm{O}$ aumento de $\mathrm{pH}$ no efluente em relação ao afluente observado na Tabela 5.5 e na Figura 5.7 não foi acompanhada pelo aumento da alcalinidade, principalmente durante as fases operacionais 3, 4 e 5, conforme observado na Tabela 5.6 e na Figura 5.8. Tal fato sugere que a alcalinidade gerada foi prontamente utilizada como solução tampão para neutralização dos ácidos presentes dentro do reator. Além disso, observa-se que os valores de alcalinidade efluente foram menores que os valores de alcalinidade afluente na última fase, evidenciando também que o reator havia perdido sua estabilidade.

A relação entre alcalinidade intermediária e alcalinidade parcial (AI/AP) ao longo das fases operacionais está apresentada na Figura 5.9. 
Figura 5.9 - Variação de valores de AI/AP do efluente.

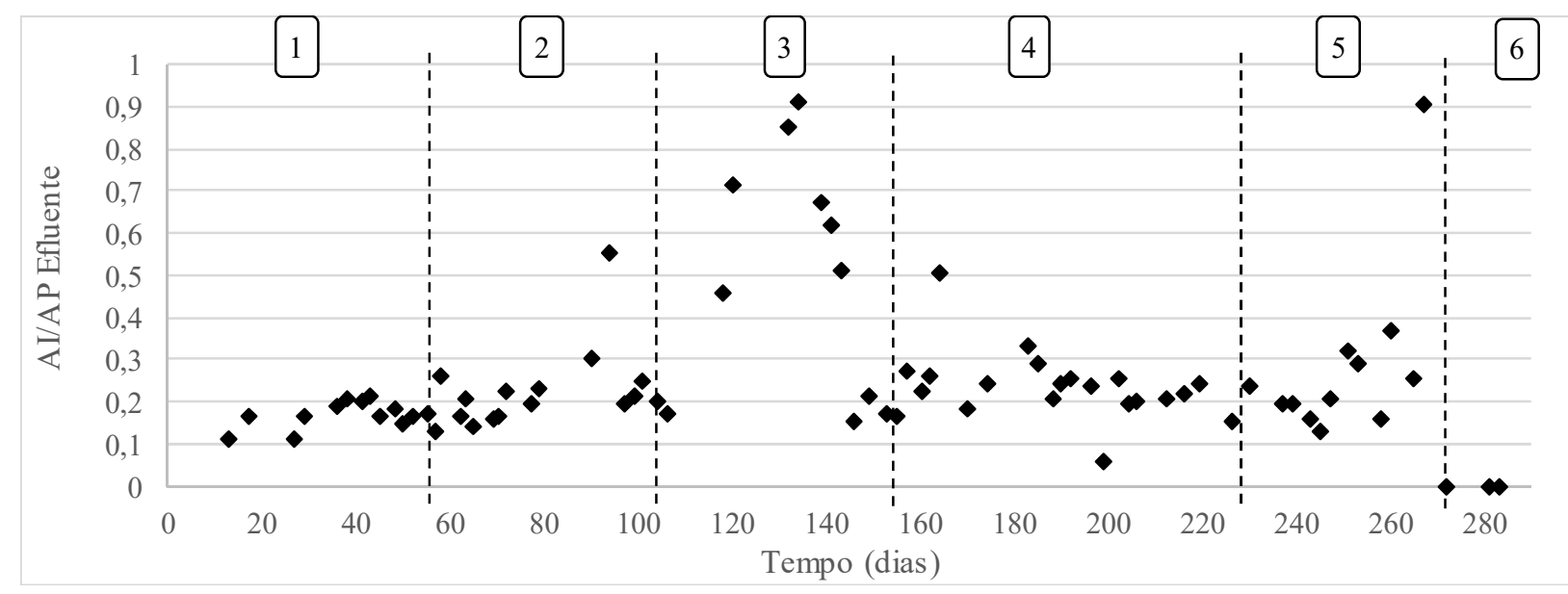

A partir da Figura 5.9, observa-se que a relação AI/AP se manteve constante nas fases 1, 2, 4 e 5 indicando que o processo de digestão anaeróbia estava equilibrado. A fase 3 apresentou variação e elevados valores de AI/AP, ilustrando a fase de adaptação da biomassa, uma vez que, nas condições subsequentes, o processo retomou a estabilidade com cargas mais elevadas que as condições 1 e 2 . Na fase 6 , os valores de $\mathrm{AI} / \mathrm{AP}$ não foram calculados porque não havia alcalinidade parcial.

A adaptação da biomassa ilustrada pelos valores maiores de AI/AP observados ao longo da fase 3 pode ser explicado pelo aumento de COV de 2,43 para 4,03 $\mathrm{kgDQO} / \mathrm{m}^{3}$.dia. Esse acréscimo foi o maior observado ao longo da operação do reator em termos porcentuais, o qual foi de $66 \%$. O maior aumento porcentual indica a maior diferença na composição da DQO afluente, justificando a necessidade de maior tempo de adaptação.

\section{4. Ácidos voláteis}

A Tabela 5.7 mostra os valores médios de ácidos voláteis totais (AVT) afluente e efluente e a Figura 5.10 mostra a variação temporal dos valores de ácidos voláteis totais. Os valores nas duas primeiras fases não foram medidos, pois se esperava que os resultados cromatográficos fossem fornecer esses valores. Porém, após uma primeira "corrida" de amostras, os valores apresentados foram todos próximos à zero. Então, resolveu-se por realizar a análise de ácidos orgânicos através do método titulométrico. 
Tabela 5.7 - Valores médios de ácidos voláteis totais afluente e efluente.

\begin{tabular}{|c|c|c|c|c|c|c|c|}
\hline \multirow{2}{*}{ Fase } & \multirow{2}{*}{$\begin{array}{c}\mathrm{COV} \\
\left(\mathrm{kgDQO} / \mathrm{m}^{3} \mathrm{dia}\right)\end{array}$} & \multicolumn{6}{|c|}{ Ácidos voláteis totais } \\
\hline & & \multicolumn{3}{|c|}{ Afluente $(\mathrm{mg} / \mathrm{L})$} & \multicolumn{3}{|c|}{ Efluente $(\mathrm{mg} / \mathrm{L})$} \\
\hline 1 & 1,74 & & - & & & - & \\
\hline 2 & 2,43 & & - & & & - & \\
\hline 3 & 4,03 & 171,11 & \pm & 35,65 & 113,56 & \pm & 47,61 \\
\hline 4 & 5,24 & 222,26 & \pm & 66,76 & 142,04 & \pm & 40,76 \\
\hline 5 & 5,68 & 346,65 & \pm & 25,29 & 136,28 & \pm & 57,79 \\
\hline 6 & 6,92 & 360,16 & \pm & 31,13 & 218,19 & \pm & 40,97 \\
\hline
\end{tabular}

Figura 5.10 - Variação dos valores de ácidos voláteis totais ao longo das fases operacionais.

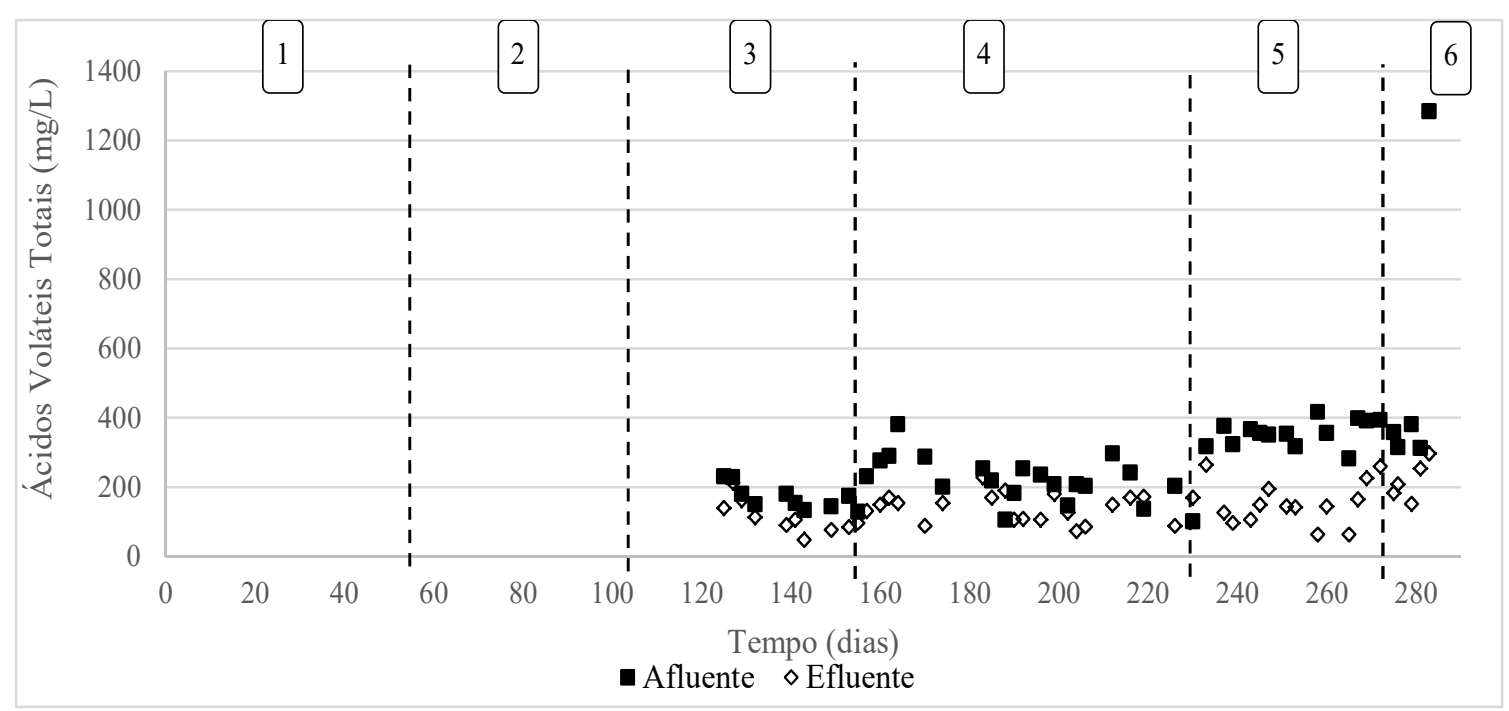

Conforme evidenciado na Tabela 5.7 e na Figura 5.10, os valores de AVT no afluente aumentaram com o avanço de fases, conforme o esperado pela geração de ácidos proveniente, por fermentação, da maior quantidade de glicerol aplicada no tanque de alimentação.

Entretanto, os valores de AVT no efluente não acompanharam esse aumento de concentração de AVT no afluente. A $4^{a}$ fase teve concentração média de AVT afluente e efluente de 222,26 e 142,04 mg/L, enquanto que a $5^{\text {a }}$ fase teve, respectivamente, valores de 346,65 e $136,28 \mathrm{mg} / \mathrm{L}$, mostrando que o reator manteve estabilidade até COV de $5,68 \mathrm{kgDQO} / \mathrm{m}^{3}$.dia e $\mathrm{pH}$ afluente de 5,84.

Assim como para outros parâmetros (produção de biogás, eficiência de remoção de DQO filtrada, alcalinidade e $\mathrm{pH}$ ), o reator apresentou indícios graduais de 
instabilidade na última fase, tendo sua concentração de AVT efluente de 165,15 mg/L no dia 267 e de $297,28 \mathrm{mg} / \mathrm{L}$ no dia 283 , evidenciando também o colapso do sistema, ao contrário das outras fases operacionais, onde o reator apresentou capacidade de adaptação.

A Tabela 5.8 e a Tabela 5.9 mostram os valores de ácido acético, propiônico e butírico médios, afluente e efluente, respectivamente. A Figura 5.11 e Figura 5.12 mostram essas mesmas variáveis ao longo dos dias de operação.

Tabela 5.8 - Valores de ácido acético, propiônico e butírico afluente nas últimas fases operacionais.

\begin{tabular}{ccccc}
\hline Fase & $\begin{array}{c}\mathrm{COV} \\
\left(\mathrm{kgDQO} / \mathrm{m}^{3} \mathrm{dia}\right)\end{array}$ & $\begin{array}{c}\text { Ác. Acético } \\
(\mathrm{mg} / \mathrm{L})\end{array}$ & $\begin{array}{c}\text { Ác. Propiônico } \\
(\mathrm{mg} / \mathrm{L})\end{array}$ & $\begin{array}{c}\text { Ác. Butírico } \\
(\mathrm{mg} / \mathrm{L})\end{array}$ \\
\hline 4 & 5,24 & 41,30 & 22,53 & 0,00 \\
5 & 5,68 & 84,51 & 128,71 & 17,95 \\
6 & 6,92 & 97,37 & 131,75 & 31,81 \\
\hline
\end{tabular}

Tabela 5.9 - Valores de ácido acético, propiônico e butírico efluente nas últimas fases operacionais.

\begin{tabular}{ccccc}
\hline Fase & $\begin{array}{c}\mathrm{COV} \\
\left(\mathrm{kgDQO} / \mathrm{m}^{3} \mathrm{dia}\right)\end{array}$ & $\begin{array}{c}\text { Ác. Acético } \\
(\mathrm{mg} / \mathrm{L})\end{array}$ & $\begin{array}{c}\text { Ác. Propiônico } \\
(\mathrm{mg} / \mathrm{L})\end{array}$ & $\begin{array}{c}\text { Ác. Butírico } \\
(\mathrm{mg} / \mathrm{L})\end{array}$ \\
\hline 4 & 5,24 & 0,00 & 0,00 & 0,00 \\
5 & 5,68 & 16,97 & 21,89 & 0,46 \\
6 & 6,92 & 90,43 & 72,30 & 7,81 \\
\hline
\end{tabular}

Figura 5.11 - Variação dos valores de ácido acético, propiônico e butírico afluente.

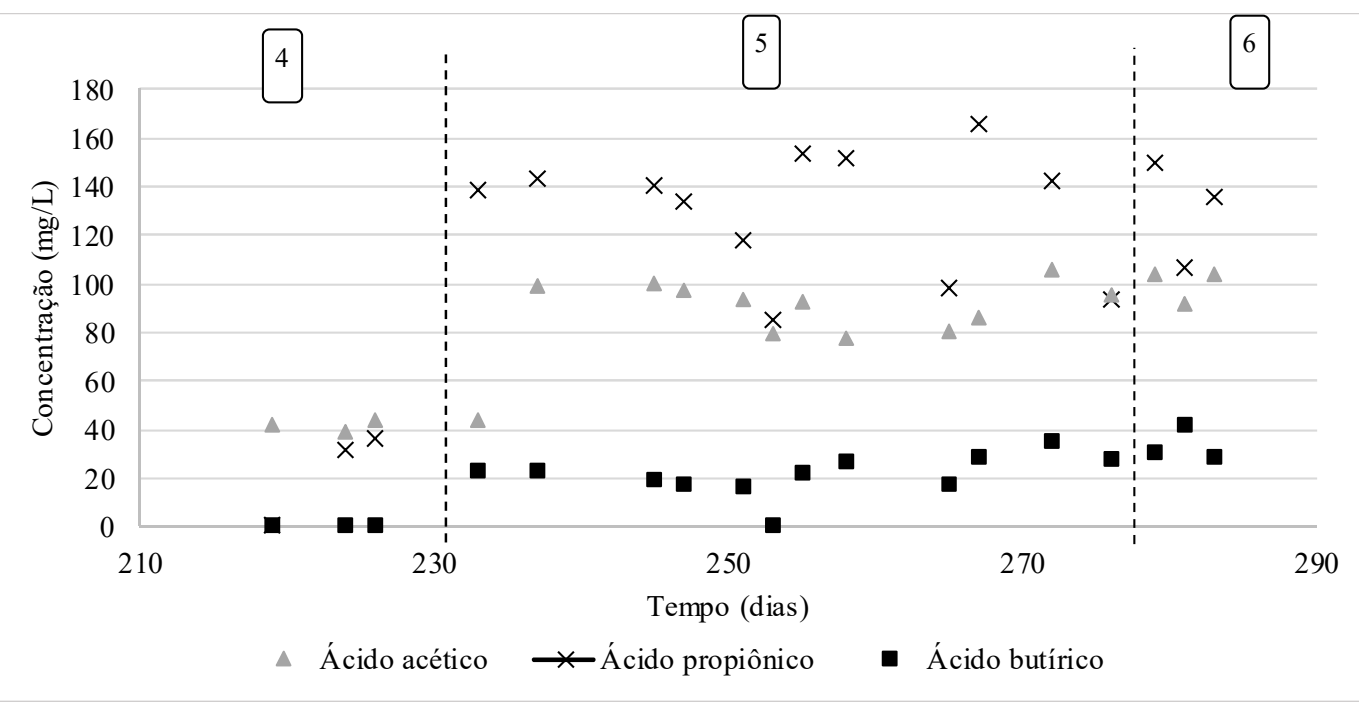


Figura 5.12- Variação dos valores de ácido acético, propiônico e butírico efluente.

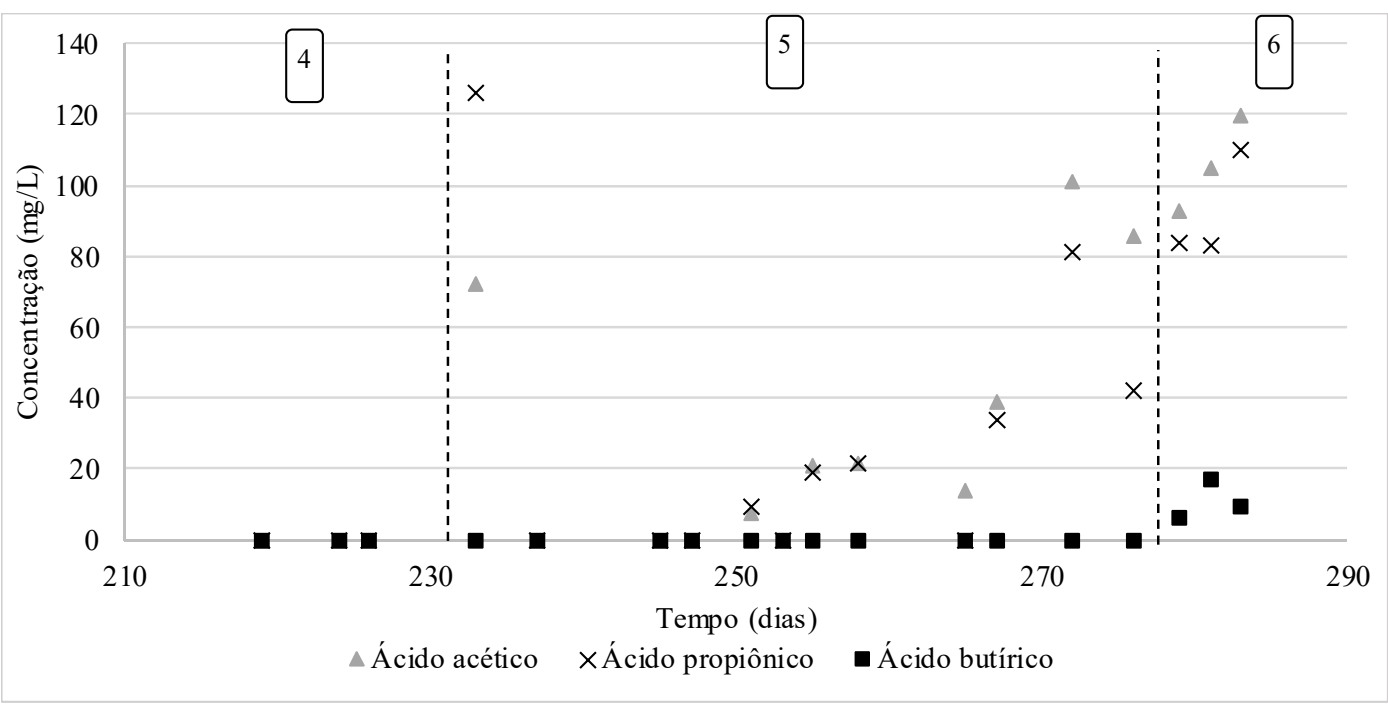

As concentrações de ácidos voláteis totais efluente observadas na Tabela 5.7, em todas as fases, se apresentou maior em relação aos valores da Tabela 5.8 e Tabela 5.9. Tal discrepância se justifica pela imprecisão do método titulométrico de quantificação de ácidos voláteis em relação ao método cromatográfico, que no caso, superestimou as concentrações de ácidos.

Conforme Tabela 5.8, Tabela 5.9, Figura 5.11 e Figura 5.12, a fase 4 teve concentração dos ácidos iguais a zero no efluente. Dessa forma, o reator foi capaz de neutralizar completamente $41,53 \mathrm{mg} / \mathrm{L}$ de ácido acético e $22,53 \mathrm{mg} / \mathrm{L}$ de ácido propiônico em COV de 5,24 kgDQO/m³.dia.

Durante a $5^{\mathrm{a}}$ fase $\left(5,68 \mathrm{kgDQO} / \mathrm{m}^{3}\right.$.dia), a concentração de ácidos afluente foi significativamente maior, porém o reator manteve baixas concentrações no efluente. A concentração de ácido acético foi de $84,51 \mathrm{mg} / \mathrm{L}$ no afluente para $16,97 \mathrm{mg} / \mathrm{L}$ no efluente, a de ácido propiônico foi de 128,71 para 21,89 mg/L e de ácido butírico foi de 17,95 para $0,46 \mathrm{mg} / \mathrm{L}$. Assim, ressalta-se que o reator manteve sua estabilidade operacional na $5^{\text {a }}$ fase.

O reator não apresentou estabilidade na conversão de ácidos na última fase (COV de 6,92 kgDQO/m³.dia). A concentração de ácido acético foi de 97,37 mg/L no afluente para 90,43 mg/L no efluente, o ácido propiônico de 131,75 para 72,30 mg/L e o ácido butírico de 31,81 para 7,81 mg/L. Assim como os outros parâmetros, a concentração de ácidos também indicou instabilidade operacional na última fase. 


\subsection{Produção de Biogás}

A Tabela 5.10 e a Figura 5.13 mostram os valores de produção de biogás medidos ao longo da operação do reator. Durante os primeiros dias de operação os valores não foram registrados pela dificuldade de instalação do equipamento de medição de biogás. Após a instalação, o registro dos valores foi prejudicado pela baixa produção observada, tendo valores que eram menores que a faixa de operação do equipamento. Por outro lado, a produção observada a partir da $2^{\mathrm{a}}$ fase foi suficiente para que o equipamento pudesse registrar os valores com maior precisão.

Tabela 5.10 - Valores de produção de biogás nas fases operacionais.

\begin{tabular}{ccccc}
\hline Fase & $\begin{array}{c}\text { COV } \\
\left(\mathrm{kgDQO} / \mathrm{m}^{3} \mathrm{dia}\right)\end{array}$ & \multicolumn{3}{c}{$\begin{array}{c}\text { Produção de Biogás } \\
(\mathrm{mL} / \mathrm{dia})\end{array}$} \\
\hline 1 & 1,74 & & - & \\
2 & 2,43 & 1246,57 & \pm & 433,77 \\
3 & 4,03 & 1276,51 & \pm & 591,18 \\
4 & 5,24 & 1452,68 & \pm & 427,78 \\
5 & 5,68 & 2790,76 & \pm & 542,55 \\
6 & 6,92 & 1430,23 & \pm & 606,42 \\
\hline
\end{tabular}

Figura 5.13 - Variação de valores de produção de biogás.

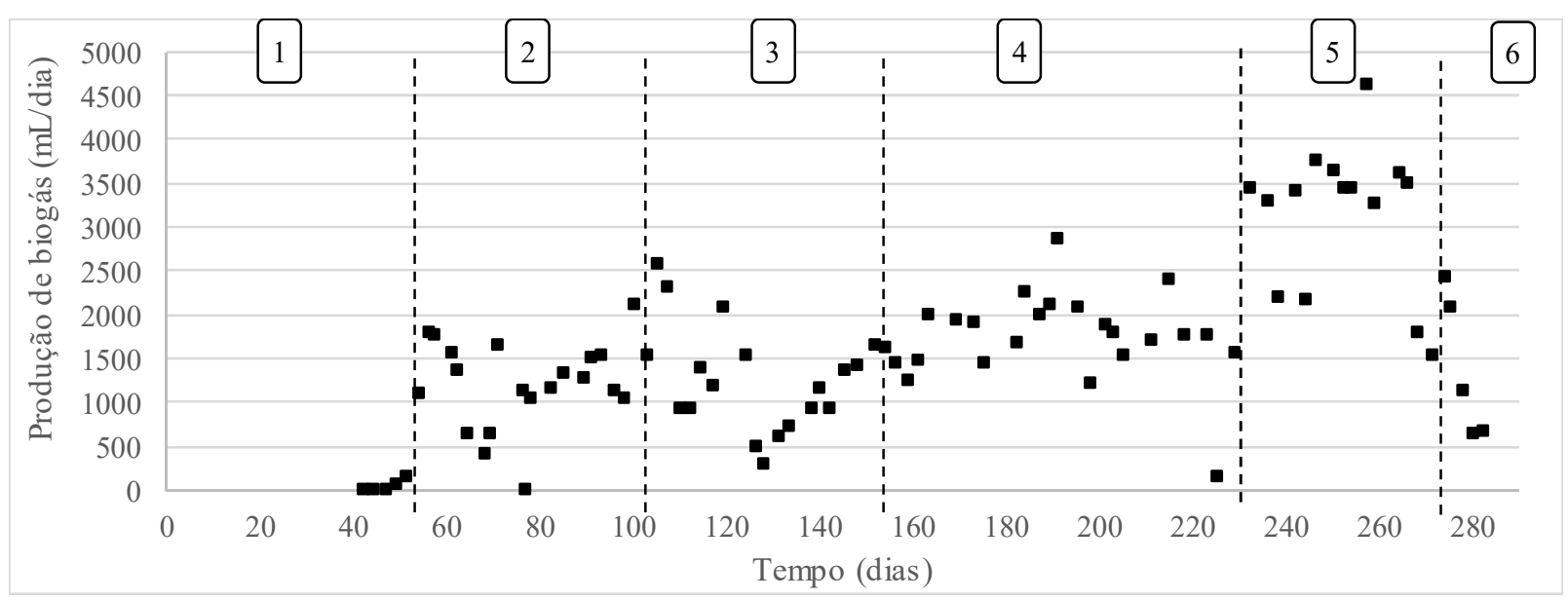

Conforme apresentado na Tabela 5.10 e na Figura 5.13, foi possível observar uma alta variação da produção de biogás dentro de cada fase operacional, principalmente pela imprecisão do equipamento de medição de gás em função dos intervalos de medida. 
O reator passou a produzir uma maior quantidade de biogás logo após o primeiro aumento de carga na transição da fase 1 para a 2, sendo que a produção passou de $143,73 \mathrm{~mL} /$ dia para $1090,16 \mathrm{~mL} /$ dia instantaneamente. Durante o resto da $2^{\mathrm{a}}$ fase, foi possível observar estabilidade de produção de biogás.

Durante a $3^{\mathrm{a}}$ fase, o reator apresentou certo aumento de produção de biogás durante os primeiros dias e depois teve uma queda por volta do $127^{\circ}$ dia de operação, tendo posteriormente um aumento gradual na sua produção. Esses valores podem ter explicação pelo maior aumento porcentual (66\%) na COV aplicada, em que o reator apresentou uma primeira resposta com aumento da produção de biogás, mas precisou de um certo tempo para adaptação até retomar a estabilidade. O mesmo comportamento foi observado e discutido em relação ao parâmetro AI/AP.

A $4^{\mathrm{a}}$ e a $5^{\mathrm{a}}$ fase de operação apresentaram estabilidade em produção de biogás, com produção média de 1452,68 e 2790,76 mL/dia, respectivamente. Considera-se que o reator apresentou uma ótima resposta na transição entre essas fases, pois houve um aumento instantâneo na produção de biogás e, a partir disso, o reator passou a produzir praticamente o dobro de biogás na $5^{\mathrm{a}}$ fase em relação à $4^{\mathrm{a}}$, com poucos dias de menor produção.

A $6^{\mathrm{a}}$ fase apresentou diminuição rápida na produção de biogás, sendo que esses valores diminuíram gradualmente, mostrando colapso do reator devido à sobrecarga orgânica, assim como observado para outros parâmetros como pH, alcalinidade, remoção de DQO e acúmulo de ácidos orgânicos.

\subsection{Composição do biogás}

A Tabela 5.11 mostra os valores médios da composição do biogás produzido em cada fase e a Figura 5.14 mostra a composição do biogás ao longo do tempo. 
Tabela 5.11 - Valores médios da composição do biogás produzido.

\begin{tabular}{ccccc}
\hline Fase & $\begin{array}{c}\mathrm{COV} \\
\left(\mathrm{kgDQO} / \mathrm{m}^{3} \mathrm{dia}\right)\end{array}$ & ${ }^{\circ \mathrm{CH}_{4}}$ & $\% \mathrm{CO}_{2}$ & $\begin{array}{c}\text { Produção de } \\
\text { metano(L/dia) }\end{array}$ \\
\hline 1 & 1,74 & $74,8 \%$ & $0,59 \%$ & \\
2 & 2,43 & $96,4 \%$ & $0,72 \%$ & 1,20 \\
3 & 4,03 & $94,1 \%$ & $1,27 \%$ & 1,20 \\
4 & 5,24 & $96,5 \%$ & $0,70 \%$ & 1,40 \\
5 & 5,68 & $95,2 \%$ & $1,92 \%$ & 2,66 \\
6 & 6,92 & $95,1 \%$ & $1,59 \%$ & 1,36 \\
\hline
\end{tabular}

Figura 5.14 - Composição do biogás produzido ao longo das fases operacionais.

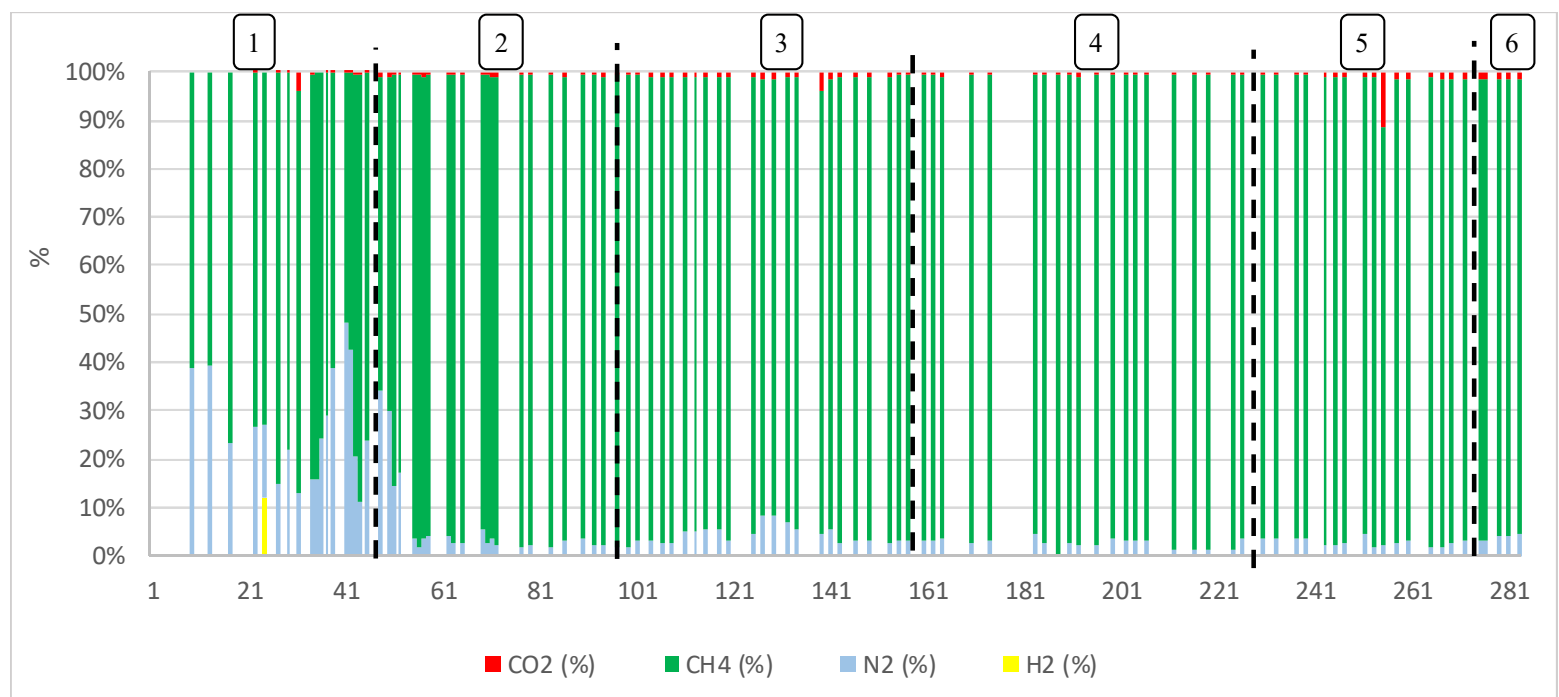

Conforme pode ser observado na Tabela 5.11 e na Figura 5.14, a composição de biogás durante a $1^{\text {a }}$ fase foi de $74.8 \%$ de metano e de $23,94 \%$ de nitrogênio. A presença de nitrogênio nessas amostras se deu pela presença de ar atmosférico, pois o reator ainda apresentava baixa produção de biogás e precisou de alguns dias para "limpeza" das tubulações do sistema de medição e coleta de biogás.

Com o aumento da COV a partir da $2^{\mathrm{a}}$ fase, o reator passou a produzir uma maior quantidade de biogás e, consequentemente, houve uma gradual predominância de metano, atingindo valores acima de 95\% na composição do biogás. Nas demais fases operacionais, o reator não apresentou aumento da porcentagem de $\mathrm{CO}_{2}$, o que seria esperado como indicador de instabilidade operacional.

A observação de aumento de produção de $\mathrm{CO}_{2}$ em reatores anaeróbios é um parâmetro importante de monitoramento, pois indica que o reator está sofrendo 
desbalanceamento, seja por variação nas condições da água residuária ou por variação nas condições ambientais (Speece, 1996). No presente trabalho, esperava-se que a condição de desbalanceamento seria o aumento de COV, que em algum momento acarretaria no aumento da produção de ácidos orgânicos e da concentração de $\mathrm{H}^{+}$, deslocando o equilíbrio de ácido carbônico pelo consumo de alcalinidade, representado na Equação 7, para a direita.

$\mathrm{H}^{+}+\mathrm{HCO}_{3}{ }^{-} \leftrightarrow \mathrm{H}_{2} \mathrm{CO}_{3} \leftrightarrow \mathrm{H}_{2} \mathrm{O}+\mathrm{CO}_{2}$

(Equação 7)

Uma hipótese para que não tenha ocorrido o aumento da concentração de $\mathrm{CO}_{2}$ no biogás é que houve consumo do mesmo por microrganismos acetogênicos autróficos, as bactérias homoacetogênicas. Os critérios para que essa hipótese seja válida são: as bactérias homoacetogênicas são persistentes e versáteis (Saady, 2013; Si et al., 2015), podem proporcionar uma maior proporção de metano no biogás (Zhang et al., 2009), podem existir em reatores acidogênicos ou metanogênicos e que o acetato produzido pode ser prontamente consumido pelas metanogênicas acetoclásticas (Liu et al., 2016).

Conforme apresentado na Tabela 5.11 e na Figura 5.14, não foi possível observar uma diferença significativa na proporção de metano no biogás durante as fases operacionais, seja quando o reator estava estável quanto instável. Tal fato sustenta a hipótese da presença das homoacetogênicas, pois os valores de metano estavam acima de $95 \%$ nas fases estáveis, o que representa um valor maior do que o geralmente é observado em reatores anaeróbios. Quando o reator estava entrando em colapso, a proporção se manteve a mesma pois as homoacetogênicas continuaram consumindo o $\mathrm{CO}_{2}$ produzido. Assim como no trabalho de Liu et al. (2016), acredita-se que a homoacetogênese tenha sido importante na maior proporção de metano no biogás, mesmo sem a ocorrência do aumento de acetato no efluente, que foi consumido pelas metanogênicas acetoclásticas.

Conforme discutido na revisão bibliográfica, as reações químicas de degradação do glicerol em metano podem ser representadas pela Equação 3 (Zhang et al., 2015), seguida pela Equação 6 (reação de homoacetogênese), que é seguida pela Equação 5 (reação de metanogênese acetoclástica). A Equação 4 mostra a metanogênese hidrogenotrófica. 


$$
\begin{array}{ll}
\mathrm{C}_{3} \mathrm{H}_{8} \mathrm{O}_{3} \rightarrow \mathrm{CH}_{3} \mathrm{COOH}+0,75 \mathrm{CH}_{4}+0,25 \mathrm{CO}_{2}+0,5 \mathrm{H}_{2} \mathrm{O} & \text { (Equação 3) } \\
4 \mathrm{H}_{2}+\mathrm{CO}_{2} \rightarrow \mathrm{CH}_{4}+\mathrm{H}_{2} \mathrm{O} & \text { (Equação 4) } \\
\mathrm{CH}_{3} \mathrm{COOH} \rightarrow \mathrm{CH}_{4}+\mathrm{CO}_{2} & \text { (Equação 5) } \\
2 \mathrm{CO}_{2}+4 \mathrm{H}_{2} \rightarrow \mathrm{CH}_{3} \mathrm{COOH}+2 \mathrm{H}_{2} \mathrm{O} & \text { (Equação 6) }
\end{array}
$$

A relação de sinergismo entre as comunidades biológicas pode ser representada pela Equação 8, que consiste na combinação estequiométrica entre as Equações 3, 4, 5 e 6.

$$
\begin{array}{lr}
\mathrm{C}_{3} \mathrm{H}_{8} \mathrm{O}_{3} \rightarrow \mathrm{CH}_{3} \mathrm{COOH}+0,75 \mathrm{CH}_{4}+0,25 \mathrm{CO}_{2}+0,5 \mathrm{H}_{2} \mathrm{O} & \text { (Equação 3) } \\
\mathrm{H}_{2}+0,25 \mathrm{CO}_{2} \rightarrow 0,25 \mathrm{CH}_{4}+0,5 \mathrm{H}_{2} \mathrm{O} & \text { (Equação 4) } \\
2 \mathrm{CH}_{3} \mathrm{COOH} \rightarrow 2 \mathrm{CH}_{4}+2 \mathrm{CO}_{2} & \text { (Equação 5) } \\
\underline{2 \mathrm{CO}_{2}+4 \mathrm{H}_{2} \rightarrow \mathrm{CH}_{3} \mathrm{COOH}+2 \mathrm{H}_{2} \mathrm{O}} & \text { (Equação 6) } \\
\mathrm{C}_{3} \mathrm{H}_{8} \mathrm{O}_{3}+5 \mathrm{H}_{2} \rightarrow 3 \mathrm{CH}_{4}+3 \mathrm{H}_{2} \mathrm{O} & \text { (Equação 8) }
\end{array}
$$

A reação representada pela Equação 8 mostra que é possível que ocorra a produção de $\mathrm{CO}_{2}$ nula a partir do glicerol. Estequiometricamente, a mesma reação poderia ser obtida a partir da Equações 3, 4 e 5, o que representaria um predomínio das metanogênicas hidrogenotróficas em relação às acetoclásticas. Porém, acredita-se que não seja esse o caso, considerando que em reatores anaeróbios cerca de apenas 33\% do metano produzido provém da atividade metanogênica hidrogenotrófica e, que, convencionalmente a matéria orgânica é convertida em $\mathrm{CO}_{2}$ na ordem de 25 a $60 \%$ em reatores anaeróbios (Demirel \& Scherer, 2008), devido à predominância das acetoclásticas. Assim como no estudo de Liu et al. (2016), acredita-se que a homoacetogênese tenha representado um papel essencial na predominância incomum de metano no biogás. No trabalho citado, a inibição dos organismos homoacetogênicos não foi capaz de proporcionar um aumento na atividade metanogênica hidrogenotrófica. 
Uma diferente hipótese é a de que o gás carbônico produzido na metanogênese acetoclástica foi convertido em outro composto não identificado, uma vez que a concentração de $\mathrm{CO}_{2}$ no gás não aumentou mesmo quando o pH diminuiu.

\subsection{Rendimento na produção de metano}

O cálculo do rendimento na produção de metano se dá pela relação entre metano produzido e a DQO removida, apresentada na Tabela 5.12 e na Figura 5.15, e a Figura 5.16 mostra um gráfico box-plot.

Tabela 5.12 - Rendimento na produção de metano ao longo das fases operacionais.

\begin{tabular}{ccccc}
\hline Fase & $\begin{array}{c}\mathrm{COV} \\
\left(\mathrm{kgDQO} / \mathrm{m}^{3} \text { dia }\right)\end{array}$ & \multicolumn{3}{c}{$\begin{array}{c}\text { Redimento na produção de metano } \\
(\mathrm{mLCH} 4 \text { gDQOremovida })\end{array}$} \\
\hline 1 & 1,74 & 20,78 & - & 31,04 \\
2 & 2,43 & 70,02 & \pm & 40,09 \\
3 & 4,03 & 36,99 & \pm & 17,65 \\
4 & 5,24 & 36,20 & \pm & 11,59 \\
5 & 5,68 & 66,64 & \pm & 14,80 \\
6 & 6,92 & 31,00 & \pm & 13,77 \\
\hline
\end{tabular}

Figura 5.15 - Rendimento da produção de metano.

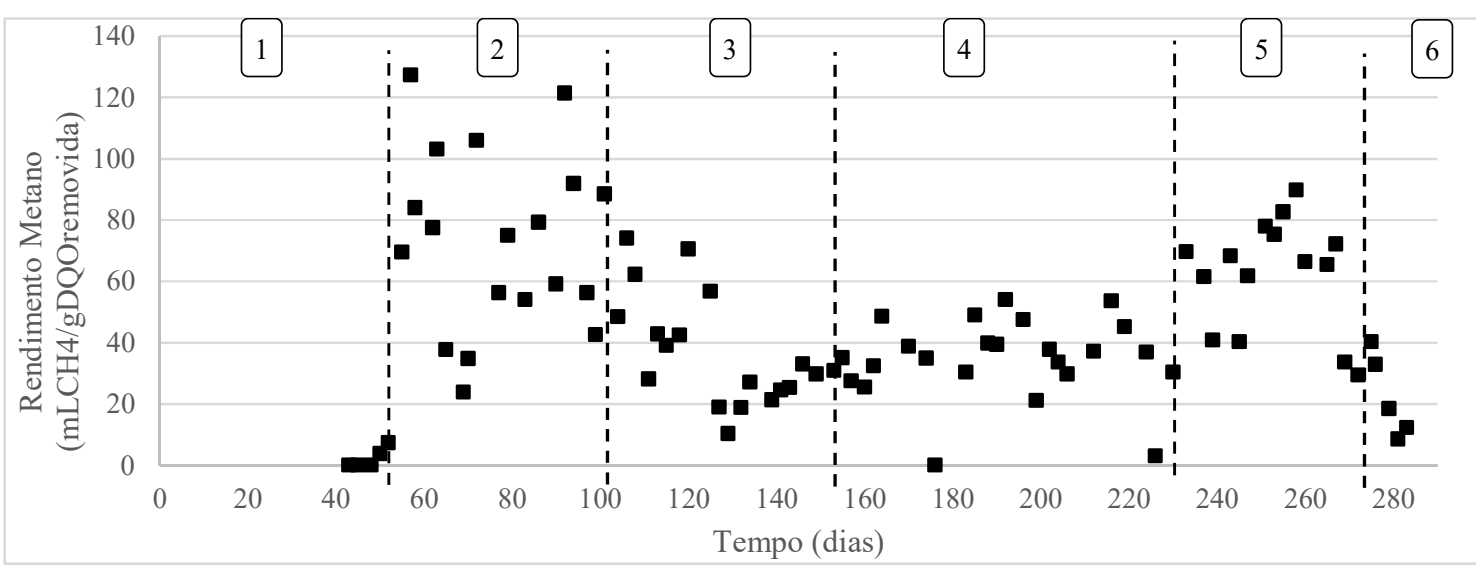


Figura 5.16 - Gráfico box-plot do rendimento da produção de metano durante as fases operacionais.

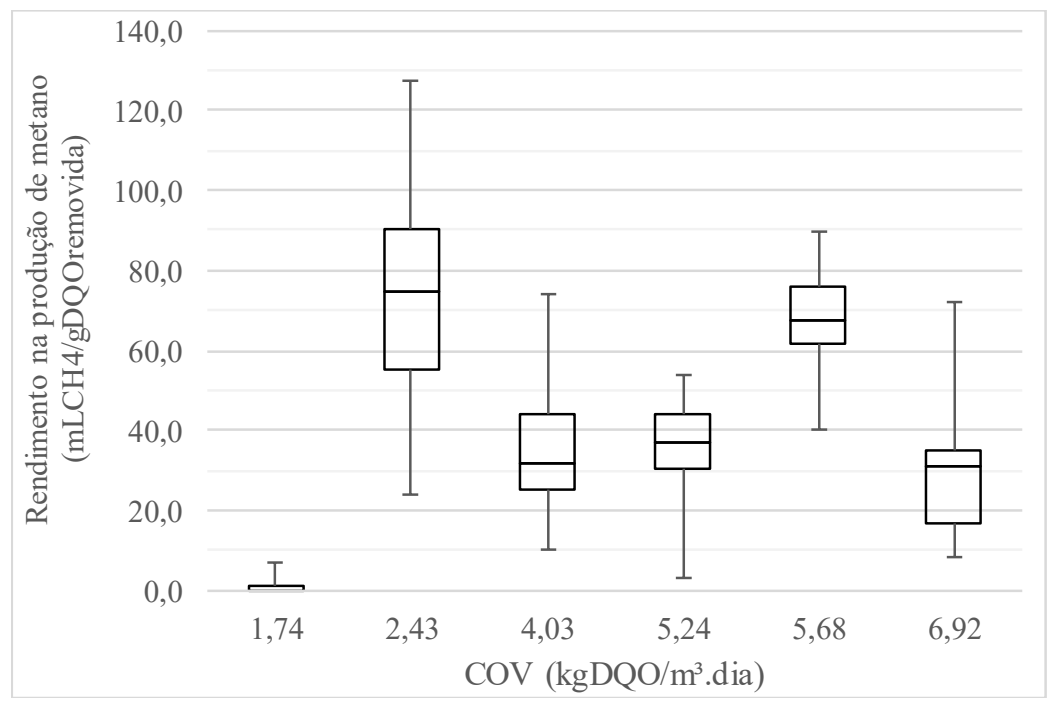

Sob condições normais de pressão e temperatura, a estimativa de produção de metano é de $350 \mathrm{ml}$ a cada $1 \mathrm{~g}$ de DQO removida. De acordo com os dados apresentados na Tabela 5.12 e na Figura 5.15, todas as fases tiveram o rendimento médio de produção de metano consideravelmente abaixo do rendimento teórico.

Após a adição de glicerol na alimentação, o reator apresentou um aumento instantâneo de rendimento de metano na $2^{\mathrm{a}}$ fase para um valor médio de 70,02 $\mathrm{mLCH}_{4} / \mathrm{gDQOremovida}$. Apesar de apresentar os valores mais altos observados durante o experimento, observa-se que foi a fase com maior instabilidade, conforme Figura 5.16.

Assim como para os parâmetros AI/AP e produção de biogás, o rendimento de produção de metano teve uma queda de eficiência na $3^{\text {a }}$ fase e uma melhora gradual a partir do $128^{\circ}$ dia de operação com a adaptação dos microrganismos à maior variação na composição do afluente, apresentando um valor médio de rendimento de 36,99 $\mathrm{mLCH}_{4} / \mathrm{gDQOremovida}$. Durante a $4^{\mathrm{a}}$ fase, o reator apresentou rendimento estável médio de 36,20 $\mathrm{mLCH}_{4} / \mathrm{gDQOremovida,} \mathrm{mantendo-se} \mathrm{na} \mathrm{mesma} \mathrm{faixa} \mathrm{da} 3^{\mathrm{a}}$ fase.

A $5^{\mathrm{a}}$ fase apresentou um maior rendimento de produção de metano, atingindo valor médio de $66,64 \mathrm{mLCH}_{4} / \mathrm{gDQOremovida,} \mathrm{principalmente} \mathrm{pela} \mathrm{maior} \mathrm{produção} \mathrm{de}$ biogás, conforme apresentado na Tabela 5.10 e Figura 5.13, mostrando também que foi a fase em que foi alcançada a melhor condição de co-digestão. A $6^{\mathrm{a}}$ fase apresentou 
rendimento que baixou gradualmente, indicando desequilíbrio na digestão anaeróbia, assim como os outros parâmetros de monitoramento.

O rendimento de produção de metano abaixo do teórico foi influenciado pela perda de metano em forma de metano dissolvido no efluente do reator. Por ser uma água residuária diluída, o esgoto sanitário geralmente apresenta uma alta fração de metano que permanece dissolvida quando submetida a tratamento anaeróbio. Segundo simulação de Lobato et al. (2012), o valor de metano perdido em forma dissolvida em reatores UASB tratando esgoto, entre 20 e $30^{\circ} \mathrm{C}$, varia entre 22 e $46 \%$. Tal fenômeno se comprova com o maior rendimento nas fases onde houve a adição de glicerol, em que o afluente possuía maior concentração de matéria orgânica e o rendimento na produção de metano pôde ser observado, ao contrário da $1^{\mathrm{a}}$ fase.

O principal fator que influenciou nos baixos valores de rendimento de produção de metano foi o fato de que o reator UASB utilizado é aberto, tendo o sistema de coleta de biogás interligado apenas ao separador trifásico. Ocasionalmente, foi possível observar que algumas bolhas de gás passavam juntamente à fase líquida para a região de coleta de efluente do reator, onde o biogás era liberado para a atmosfera, não sendo contabilizado pelo equipamento de medição.

Além da perda de metano na forma dissolvida no efluente e da perda pelo sistema aberto, o baixo rendimento na produção de metano também pode ter sido influenciado pela hipótese do direcionamento da conversão da matéria orgânica a outro composto, e não para o processo de metanização, apesar da alta remoção de DQO.

\subsection{Atividade metanogênica específica}

Os valores obtidos através do teste de AME foram: 0,1126, 0,1134 e 0,1136 gDQO- $\mathrm{CH}_{4} / \mathrm{gSSV}$.dia, sendo representados, portanto por um valor médio de 0,1132 gDQO- $\mathrm{CH}_{4} / \mathrm{gSSV}$.dia. Considerando as concentrações de sólidos do reator, o volume total de lodo e que $1 \mathrm{~mol}$ de gás ocupa 22,4 L, que correspondem a $64 \mathrm{~g}$ de DQO, os cálculos obtidos a partir do teste de AME estão apresentados na Tabela 5.13. 
Tabela 5.13 - Cálculos realizados a partir do teste de AME.

\begin{tabular}{ccc}
\hline SST lodo & 27,1 & $\mathrm{~g} / \mathrm{L}$ \\
SSV lodo & 21,9 & $\mathrm{~g} / \mathrm{L}$ \\
SSV/SST & 0,808 & \\
Volume de lodo no reator & 3,5 & $\mathrm{~L}$ \\
Massa de SSV no reator & 2,83 & $\mathrm{~g}$ \\
Produção potencial teórica de metano & 8,68 & $\mathrm{gDQO}_{-} \mathrm{CH}_{4} / \mathrm{dia}$ \\
Produção potencial teórica de metano & 3,04 & $\mathrm{LCH}_{4} / \mathrm{dia}$ \\
\hline
\end{tabular}

Conforme a Tabela 5.13, observa-se que o lodo utilizado possuía potencial teórico de produção de metano de $3,04 \mathrm{~L} \mathrm{CH}_{4} /$ dia. Comparando esse valor com os apresentados na Tabela 5.11, verifica-se que esse valor se aproxima da produção média de biogás observada na $5^{\text {a }}$ fase operacional, que foi de 2,66 L/dia, conforme Tabela 5.11 , ressaltando que a COV de $5,68 \mathrm{kgDQO} / \mathrm{m}^{3}$.dia na $5^{\text {a }}$ fase foi a que apresentou a melhor condição de co-digestão do experimento. 


\section{CONCLUSÕES}

Os resultados experimentais obtidos mostram que a adição de glicerol ao afluente de reator UASB tratando esgoto sanitário é adequada para o aumento da produção de metano nas condições propostas. Com o aumento progressivo de carga orgânica aplicada, o processo foi estável até $\mathrm{COV}$ de $5,68 \mathrm{kgDQO} \cdot \mathrm{m}^{-3} \cdot \mathrm{d}^{-1}$, tendo alcançado produção cerca de três vezes maior que a condição de operação sem glicerol e eficiência de remoção de DQO de $85 \%$. O bom desempenho do reator até essa COV ocorreu sem adição de álcali, com manutenção de $\mathrm{pH}$ próximo ao neutro, porcentagem de metano no biogás acima de $95 \%$. Os resultados obtidos no teste de AME mostraram também o melhor desempenho do reator na COV de 5,68 $\mathrm{kgDQO} . \mathrm{m}^{-3} \cdot \mathrm{d}^{-1}$, por conta da proximidade dos valores obtidos com o valor de potencial teórico. Com a aplicação de COV de $6,92 \mathrm{kgDQO} \cdot \mathrm{m}^{-3} \cdot \mathrm{d}^{-1}$, o reator apresentou instabilidade na produção de biogás, na remoção de matéria orgânica e no $\mathrm{pH}$, indicando sobrecarga orgânica

A baixa produção de $\mathrm{CO}_{2}$ representou um desempenho incomum do reator, tanto nas fases estáveis quanto nas instáveis e é sustentada pela hipótese da ocorrência de atividade homoacetogênica no reator, em uma relação de sinergismo com as diversas comunidades microbiológicas responsáveis pela digestão anaeróbia.

Diferentemente dos recentes estudos realizados sobre co-digestão anaeróbia no tratamento de efluentes, onde foram utilizados tempos de detenção hidráulica na ordem de dias, o presente trabalho se mostrou mais eficiente neste mérito, pois foi utilizado um tempo de detenção hidráulica de 8 horas, fato que representaria um melhor aproveitamento de volume e área em casos de unidades de reatores em escala plena.

O grande número de reatores anaeróbios no Brasil mostra que o processo codigestivo proposto no presente trabalho representou uma ótima solução para lidar com o aumento da geração de glicerol, proporcionando adequação ambiental do resíduo e pelo potencial de geração de energia a partir do aproveitamento do metano do biogás. 


\section{REFERÊNCIAS BIBLIOGRÁFICAS,}

AGRAWAL, L.; HARADA, H.; TSENG, I.; OKUI, H.; Treatment of dilute wastewater in a UASB reactor at a moderate temperature: microbiological aspects. Journal of Fermentation and Bioengineering. 83. N. 2. 185-195. 1997.

APHA. Standard methods for the examination of water and wastewater. 21. Ed. Washington: American Public Health Association. 2005.

AQUINO, S. F. D.; CHERNICHARO, C. A. D. L.; FORESTI, E.; SANTOS, M. D. L. D.; MONTEGGIA, L. O. Metodologias para determinação da atividade metanogênica específica (AME) em lodos anaeróbios. Engenharia Sanitária e Ambiental. 12. 192201. 2007.

ATHANASOUliA, E.; MELIDIS, P.; AIVASIDIS, A. Co-digestion of sewage sludge and crude glycerol from biodiesel production. Renewable Energy. v. 62. p.73-78. 2014.

BABA, Y.; TADA, C.; WATANABE, R.; FUKUDA, Y.; CHIDA, N.; NAKAI, Y.; Anaerobic digestion of crude glycerol from biodiesel manufacturing using a large-scale pilot plant: Methane production and application of digestion sludge as fertilizer. Bioresource Technology. v. 140. p. 342-348. 2013.

BRASIL. Resolução no 2 de 27 de abril de 2009. Estabelece em quatro por cento, em volume, o percentual mínimo obrigatório de adição de biodiesel ao óleo diesel comercializado ao consumidor final, de acordo com o disposto no art. $2^{\circ}$ da Lei $n^{\circ}$ 11.097, de 13 de janeiro de 2005. Diário Oficial [da] República Federativa do Brasil. Brasília, DF, de 18/05/2009, n.92, s.1, p.90. 2009a.

BRASIL. Resolução ${ }^{\circ} 6$ de 16 de setembro de 2009. Estabelece em cinco por cento, em volume, o percentual mínimo obrigatório de adição de biodiesel ao óleo diesel comercializado ao consumidor final, de acordo com o disposto no art. $2^{\circ}$ da Lei $n^{\circ}$ 11.097, de 13 de janeiro de 2005. Diário Oficial [da] República Federativa do Brasil. Brasília, DF, de 26/10/2009, n. 204, s.1, p.99. 2009 b.

BRASIL. Lei $\mathrm{n}^{\circ} 13.033$ de 24 de setembro de 2014. Dispõe sobre a adição obrigatória de biodiesel ao óleo diesel comercializado com o consumidor final; altera as Leis $\mathrm{n}^{\mathrm{os}}$ 
9.478, de 6 de agosto de 1997, e 8.723, de 28 de outubro de 1993; revoga dispositivos da Lei $\mathrm{n}^{\mathrm{O}}$-11.097, de 13 de janeiro de 2005; e dá outras providências. Diário Oficial [da] República Federativa do Brasil. Brasília, DF, de 24/09/2014. 2014.

BRASIL. Lei $\mathrm{n}^{\circ} 13.263$ de 23 de março de 2016. Altera a Lei $\mathrm{n}^{\circ} 13.033$, de 24 de setembro de 2014, para dispor sobre os percentuais de adição de biodiesel ao óleo diesel comercializado no território nacional. Diário Oficial [da] República Federativa do Brasil. Brasília, DF, de 24/3/2016, s.1, p.1. 2016.

BUCHAUER, K. A comparison of two simple titration procedures do determine volative fatty acids in influentes to waste-water and sludge treatment processes. Water S.A, v. 24, n. 1, p. 49-56, 1998.

CASTRILLÓN, L.; FERNÁNDEZ-NAVA, Y.; ORMAECHEA, P.; MARAÑON, E. Optimization of biogás production from cattle manure by pre-treatment with ultrasound and co-digestion with crude glycerin. Bioresource Technology. v. 102. p. 7845-7849. 2011.

CHERNICHARO, C. A. L.; Biological Wastewater Treatment Series: vol. 4 Anaerobic Reactors. IWA Publishing, London, UK. 2007.

CHERNICHARO, C. A. L.; Princípios do tratamento biológico do tratamento de águas residuárias - Volume 5: Reatores Anaeróbios. Departamento de Engenharia Sanitária e Ambiental, DESA/UFMG, Belo Horizonte, Brasil. 1997.

CHERNICHARO, C. A. L.; Discussão dos Resultados da Pesquisa: Novos Caminhos para o Setor. Painel na 46 ${ }^{a}$ Assembleia Nacional da ASSEMAE. Biogás de Reatores Anaeróbios: Estado da Arte no Brasil. Projeto Probiogás. 2016.

COOKNEY, J.; MCLEOD, A.; MATHIOUDAKIS, V.; NCUBE, P.; SOARES, A.; JEFFERSON, B.; MCADAM, E. J. Dissolved methane recovery from anaerobic effluents using hollow fibre membrane contactors. Journal of Membrane Science. V.502. p.141-150. 2015.

COSTA, T. B. Produção de hidrogênio e metano a partir de glicerol bruto e cultura mista em reatores aneróbios de leito fluidizado termofilicos. Dissertação (Mestrado) Programa de Pós-Graduação em Engenharia Química da Universidade Federal de São Carlos. São Carlos. 2017. 
DASARI, M. A., KIATSIMKUl, P. P., SUTTERLIN, W. R., SUPPES, G. J. Lowpressure hydrogenolysis of glycerol to propylene glycol. Applied Catalysis. A: General 281, 225-231. 2005.

DEMIREL, B.; SCHERER, P. The role of acetotrophic and hydrogenotrophic methanogens during anaerobic conversion of biomass to methane: A review. Environmental Science Biotechnology. V. 7. 173-190. 2008.

DRAKE, H.L., KUSEL, K., MATTHIES, C. Acetogenic prokaryontes. In: DWORKIN, M., FALKOW, S. ROSENBERG, E., SCHLEIFER, K.H., STACKEBRANDTM E. (Eds.), The Prokaryontes. Springer, New York p. 354-420. 2006.

FOUNTOULAKIS, M. S.; PETOUSI, I.; MANIOS, T. Co-digestion of sewage sludge with glycerol to boost biogas production. Waste Management, v. 30, n. 10, p. 1849$1853,2010$.

GERVAJIO, G. C.; Fatty acids and derivates from coconut oil. In: Bayley's Industrial Oil And Fat Products, 6 ${ }^{\text {a }}$ ed. Jonh Wiley \& Sons, Inc. 2005.

GROSSER, A. The influence of decreased hydraulic retention time on the performance and stability of co-digestion of sewage sludge with grease trap sludge and organic fraction of municipal waste. Journal of Environmental Management. 203. 11431157. 2017.

HENEARES, M.; FERRERO, P.; SAN-VALERO, P.; MARTÍNEZ-SORIA, V.; IZQUIERDO, M. Performance of polypropylene membrane contactor for the recovery of dissolved methane from anaerobic effluents: mass transfer evaluation, long-term operation and cleaning strategies. Journal of Membrane Science. 2018.

JAVANI, A.; HASHEMINEJAD, M.; TAHVILDARI, K.; TABATABAEI, M. High quality potassium phospate production through step-by-step glycerol purification: A strategy to economize biodiesel production. Bioresource Technology. v. 104. p. 788790. 2012.

KURAHASHI, K.; KIMURA, C.; FUJIMOTO, Y.; TOKUMOTO, H. Value-adding conversion and volume reduction of sewage sludge by anaerobic co-digestion with crude glycerol. Bioresource Technology. 232. 119-125. 2017.

\section{LETTINGA}


LIN, Y. C. Catalytic valorization of glycerol to hydrogen and syngas. International Journal Hydrogen Energy. v.38. p 2678-2700. 2013.

LIU, R., HAO, X., WEI, J. Function of homoacetogenesis on the heterophobic methane production with exogenous $\mathrm{H}_{2} / \mathrm{CO}_{2}$ involved. Chemical Engineering Journal. v. 284. p. 1196-1203. 2016.

LOBATO, L. C. S.; CHERNICHARO, C. A. L.; SOUZA, C. L. Estimates of methane loss and energy recovery potential in anaerobic reactors treating domestic wastewater. Water Science and Technology. V.66. 2012.

MA, J.; VAN WAMBEKE, M.; CARBALLA, M.; VERSTRAETE, W. Improvement of the anaerobic treatment of potato processing wastewater in a UASB reactor by -codigestion of glycerol. Biotechnology letters. v. 30., p. 861-867, 2008.

MARTINS, T. H. Apostila sobre o uso de teste manométrico para determinação de atividade metanogênica específica em lodos biológicos. Rotina de operação e análise de biodegradação manométrica. 2015.

MATA-AlVAREZ, J., DOSTA, J., MACÉ, S. \& ASTALS, S. 2011. Codigestion of solid wastes: A review of its uses and perspectives including modeling. Critical Reviews in Biotechnology, 31(2):99-111.

METCALF \& EDDY. Tratamento de Efluentes e Recuperação de Resíduos. Tradução: Ivanildo Hespanhol, José Carlos Mierzwa - 5. Ed. - Porto Alegre: AMGH. xxvii, 1980p. 2016.

MCCARTY, P. L.; BAE, J.; KIM, J. Domestic wastewater treatment as a net energy producer - Can this be achieved?. Environmental Science \& Technology. 45 (17). 7100-7106. 2011.

MONTEIRO, M. R.; KUGELMEIER, C. L.; PINHEIRO, R. S.; BATALHA, M. O.; CÉSAR, A. S. Glycerol from biodiesel production: Technological paths of sustaintability. Renewable and Sustainable Energy Reviews. 88. 109-122. 2018.

MOURA, R. B. de.; Remoção de matéria orgânica e nitrogênio de esgoto sanitário em reator de leito estruturado submetido à aeração intermitente e recirculação do efluente. Tese (Doutorado) - Programa de Pós-Graduação e Área de Concentração em Hidráulica e Saneamento - Escola de Engenharia de São Carlos da Universidade de São Paulo. São Carlos. 2014. 
NIE, Y., LIU, H., DU, G., CHEN, J. Enhacement of acetate production by a novel coupled syntrophic acetogenesis with homoacetogenesis process. Process Biochemistry. V.42. 2007.

NOYOLA, A.; SAGASTUME, J. M. M.; HERNANDEZ, J. E. L. Treatment of biogasproduced in anaerobic reactors for domestic wastewater: odor control and nergy/resource recovery. Reviews in Enviromental Science and Bio/Technology, v.5, p.93-114, 2006.

NOYOLA, A.; PADILLA-RIVERA, A.; MORGAN-SAGASTUME, J. M.; GUERECA, L. P.; HERNÁNDEZ-PADILLA, F. Typology of municipal wastewater treatment Technologies in Latin America. Clean - Soil, Air, Water. 40. 926-932. 2012.

NUCHDANG, S.; PHALAKORNKULE, C. Anaerobic digestion of glycerol and codigestion of glycerol and pig manure. Journal of Environmental Management. 101, p. 164-172. 2012.

OZMIHCI, S., KARGI. F. Dark fermentative bio-hydrogen production from waste wheat starch using co-culture with periodic feeding: Effects os substrate loading rate. International Journal of Hydrogen Energy. v.36. p 7089-7093. 2011.

POLETO, L.; SOUZA, P.; MAGRINI, F. E.; BEAL, L. L.; TORRES, A. P. R.; SOUSA, M. P.; LAURINO, J. P.; PAESI, S.; Selection and identification of microorganisms presente in the treatment of wastewater and activated sludge to produce biohydrogen from glycerol. International Journal of Hydrogen Energy. v.41. p 4374-4381. 2016.

Probiogás. Guia técnico de aproveitamento energético de biogás em estações de tratamento de esgoto / Probiogás. organizadores, Ministério das Cidades, Deutsche Gesellschaf für Internationale Zusammenarbeit GmbH (GIZ) . - Brasília, DF : Ministério das Cidades, 2015. 183 p. : il. - (Aproveitamento energético de biogás em estações de tratamento de esgoto: 1). Brasil. Secretaria Nacional de Saneamento Ambiental. 2015.

PROSAB. Reatores Anaeróbios - Proposta de Ação Conjunta entre Pesquisadores e Empresas de Saneamento apoiada pela FINEP. PROSAB. Encontro realizado durante o $26^{\circ}$ Congresso Brasileiro de Engenharia Sanitária e Ambiental. Porto Alegre-RS. 2011.

REN21. Renewables 2016. Global Status Reports. REN21, Secretariat, Paris. 2016. 
RIPLEY, L. E.; BOYLE, W. C.; CONVERSE, J. C. Improved Alkalimetric Monitoring for Anaerobic Digestion of High-Strength Wastes. Water Environmental Federation. V. 58, n. 5, p. 406-411. 1986.

RODRÍGUEZ-ABALDE, Á.; FLOTATS, X.; FERNÁNDEZ, B.; Optimization of the anaerobic co-digestion of pasteurized slaughterhouse waste, pig slurry and glycerine. Waste Management. 61. 521-528. 2017.

SAADI, N. M. C. Homoacetogenesis during hydrogen production by mixed cultures mixed fermentation: unresolved challenge. International Journal of Hydrogen Energy. v.38. 2013.

SANTOS, V. F. Biodiesel: O combustível ecológico. Bolsista de Valor. Revista de divulgação do Projeto Universidade Petrobrás e IF Fluminense v.2. n.1. p 215-219. 2012.

SI, B., LI, J., LI, B., ZHU, Z., SHEN, R., ZHANG, Y., LIU, Z. The role of hydraulic retention time on controlling methanogenesis and homoacetogenesis in biohydrogen production using upflow anaerobic sludge blanket (UASB) reactor and packed bed reactor (PBR). International Journal of Hydrogen Energy. v.40. 2015.

SILES, J. A.; MARTÍN, M. A.; CHICA, A. F.; MARTÍN, A.; Anaerobic co-digestion of glycerol and wastewater derived from biodiesel manufacturing. Bioresource Technology. v. 101, n. 16, p. 6315-6321. 2010.

SILES LÓPEZ, J.Á., MARTÍN SANTOS, M.A., CHICA PÉREZ, A.F., MARTÍN MARTÍN, A. Anaerobic digestion of glycerol derived from biodiesel manufacturing. Bioresource Technology. 100, 5609-5615. 2009.

SLINN M, KENDALL K, MALLON C, ANDREWS J. Steam reforming of biodiesel by-product to make renewable hydrogen. Bioresource Technology.;99:5851 e8. 2008.

SPEECE, R. E. \& McCARTY, P. L.; Nutrient requirements and biological solids accumulation in anaerobic digestion. Advances in Water Pollution Research. v. 2, Pergamon Press, London. p 305. 1964.

SPEECE, R. E.; Anaerobic Biotechnology for Industrial Wastewaters. Nashville, Tennessee, Archae Press. 1996.

STATTMAN, S. L.; MOL, A. P. J. Social sustainability of Brazilian biodiesel: the role of agricultural cooperatives. Geoforum. 54. 282-294. 2014. 
VALENTE, V. B.; Análise de viabilidade econômica e escala mínima de uso do biogás de reatores anaeróbios em Estações de Tratamento de Esgoto no Brasil. Dissertação de mestrado - UFRJ/ COPPE/ Programa de Planejamento Energético. Rio de Janeiro: UFRJ/COPPE. 2015.

VIANA, M. B.; Produção de biogás a partir de glicerol oriundo de biodiesel. Dissertação de Mestrado - Programa de Pós-graduação e Área de concentração em Hidráulica e Saneamento. Escolha de Engenharia de São Carlos da Universidade de São Paulo. 2011.

WANG, Z. X.; ZHUGE, J.; FANG, H.; PRIOR, B.A. Glycerol production by microbial fermentation: a review. Biotechnology Advances. v. 19, n. 3, p. 201-23, 2001.

WOHLGEMUT, O. Co-digestion of hog manure with glycerol to boost biogas and methane production. Msc. Thesis, University of Manitoba, Winnipeg, Manitoba, 2009.

XIE, S.; HAI, F. I.; ZHAN, X.; GUO, W.; NGO, H. H.; PRICE, W. E.; NGHIEM, L. D. Anaerobic co-digestion: A critical review of mathematical modelling for performance optimization. Bioresource Technology. v. 222, p. 498-512. 2016.

ZAHEDI, S.; RIVERO, M.; SOLERA, R.; PEREZ, M. Mesophilic anaerobic codigestion of sewage sludge with glycerine: Effect of solids retention time. Fuel. 215. 285-299. 2018.

ZANETte, A. L.; Potencial de Aproveitamento Energético do Biogás no Brasil. Dissertação de Mestrado - UFRJ/COPPE/Programa de Planejamento Energético. 